\title{
TEXT IN CONTEST: GENDER AND THE CONSTITUTION FROM A SOCIAL MOVEMENT PERSPECTIVE
}

\author{
REVA B. SIEGEL ${ }^{\dagger}$ \\ INTRODUCTION
}

The American feminist movement has twice mobilized for constitutional change. The constitutional amendment secured by the firstwave feminist movement is no longer of consequence, while the constitutional amendment sought by the second-wave feminist movement was never ratified. Yet today, courts and commentators agree that the Constitution guarantees women equality, even if that guarantee was never specifically authorized by the Constitution's framers. What understanding of our constitutional tradition might we glean from this story of constitutional change?

In a recent article in the Harvard Law Review, David Strauss contends that the story of the Nineteenth Amendment and the Equal Rights Amendment (ERA) proves the irrelevance of amendments in our constitutional tradition, and more generally illustrates the insignificant role that constitutional text plays in the articulation of constitutional norms.' Women did not need the Nineteenth Amendment to obtain the right to vote any more than they needed the ERA to obtain modern sex equality law. Evolving gender mores would have led to the enfranchisement of women by statute, just as evolving gender mores led the judiciary to afford women constitutional protection from regulation that enforces archaic gender norms. ${ }^{2}$ The manner in which our constitutional tradition has progressively incorporated a gender equality commitment demonstrates, for Strauss, that the story

\footnotetext{
${ }^{\dagger}$ Nicholas deB. Katzenbach Professor, Yale Law School. Many thanks to Bruce Ackerman, Akhil Amar, Jack Balkin, William Forbath, Larry Kramer, Jim Pope, and Robert Post for comments on the manuscript, and to Janna Hansen and Sarah Lawsky for research assistance.

${ }^{\prime}$ David A. Strauss, The Irrelevance of Constitutional Amendments, 114 HARV. L. REV. 1457 (2001) [hereinafter Strauss, Irrelevance].

${ }^{2}$ See id. at 1476-78 (asserting that constitutional law today is essentially the same as it would have been had the ERA been adopted); id. at 1499-503 (suggesting that the lack of resistance to enforcement of the Nineteenth Amendment reveals that the Amendment "ratif[ied] a permanent shift in political culture").
} 
about our Constitution that originalists and textualists tell is descriptively incorrect, and, as he elsewhere argues, normatively unattractive as well."

In this Article, I will be drawing on the stories of the ERA and the Nineteenth Amendment to demonstrate that the Constitution's text plays a more significant role in our constitutional tradition than Strauss contends. My purpose is not to defend the arguments of originalists and textualists that Strauss is endeavoring to refute, ${ }^{4}$ but instead to explore some alternatives to the traditions of reasoning about text that Strauss criticizes.

As Strauss observes, text is privileged in the American constitutional tradition "because someone with authority adopted it"; at root, "[t]his authoritative tradition sees the law as the command of a sovereign." In the American tradition, it is the People who are sovereign, authors of the Constitution's text.

Strauss challenges this understanding of our constitutional tradition on positive and normative grounds. As Strauss understands our constitutional tradition, text is inessential to constitutional interpretation and amendment is inconsequential as a method of constitutional change. "Discrete, decisive, formal amendatory acts, supposedly by the sovereign People, are at most a minor part of the process of constitutional change." Invocation of the Constitution's text keeps alive the myth that it is the People who are authors of the Constitution. But in fact it is judges making judgments about precedent, tradition, and evolving social understandings who make decisions in the Consti-

See David A. Strauss, Common Law Constitutional Interpretation, 63 U. CHI. L. REV. 877,879 (1996) [hereinafter Strauss, Common Law] ("The common law approach ... is more justifiable in abstract terms than textualism or originalism, and provides a far better account of our practices."); see also Strauss, Irrelevance, supra note 1, at 1461 \& $\mathbf{n} .8$ (noting the conceptual linkages between articles arguing that amendments and text play a limited role in our constitutional tradition).

4 Strauss observes:

[T] he terms of debate in American constitutional law continue to be set by the view that principles of constitutional law must ultimately be traced to the text of the Constitution, and by the allied view that when the text is unclear the original understandings must control. An air of illegitimacy surrounds any alleged departure from the text or the original understandings. . . But textualism and originalism remain inadequate models for understanding American constitutional law.

Strauss, Common Law, supra note 3, at 878-79.

5 Id. at 885.

${ }^{\circ}$ Strauss, Irrelevance, supra note 1, at 1465. 
tution's name: “[I]t is the common law approach, not the approach that connects law to an authoritative text, or an authoritative decision by the Framers or by 'we the people,' that best explains, and best justifies, American constitutional law today."7

In this Article, I challenge Strauss's claims about the "irrelevance" of the ERA and the Nineteenth Amendment with the objective of calling into question this common-law, and fundamentally juricentric, understanding of our constitutional tradition.

Both the ERA and the Nineteenth Amendment demonstrate how the text of the Constitution makes the terms of our constitutional tradition amenable to contestation by mobilized groups of citizens, acting inside and outside the formal procedures of the legal system. It is, most often, as text that the Constitution is the object of social movement struggle. Text matters in our tradition because it is the site of understandings and practices that authorize, encourage, and empower ordinary citizens to make claims on the Constitution's meaning.

These features of our tradition disappear in Strauss's account, because as Strauss models our constitutional tradition, he focuses, nearly exclusively, on the official pronouncements of judges. Not only judges and courtroom lawyers, however, but elected officials and ordinary citizens regularly make claims about the Constitution. In so doing, they may follow the Court's reading of the Constitution, but often they do not, explicitly "differentiat[ing] between the Constitution and the Court." standings about the Constitution as text authorizes nonjuridical speakers to make claims about the Constitution that diverge from the Court's. ${ }^{9}$ Americans act on these understandings through a variety of

${ }^{7}$ Strauss, Common Law, supra note 3, at 879.

8 Michael Kammen, a Machine That Would Go of Itself: The Constitution IN AMERICAN CULTURE 9 (1986) (invoking the claims of Andrew Jackson, Abraham Lincoln, and Franklin Delano Roosevelt).

${ }^{9}$ Sandy Levinson describes this body of understandings as the "Protestant" strain in the American constitutional tradition. SANFORD LEVINSON, CONSTITUTIONAL FAITH 27 (1988). He explains, “' [P] rotestantism' herein refers to either (1) an emphasis on the exclusivity of written Scripture or text as the basis of doctrine, or (2) the legitimacy of individual (or at least relatively nonhierarchical communitarian) interpretation as against the claims of a specific, hierarchically organized institution." Id. Hendrick Hartog describes this understanding as "a faith that the received meanings of constitutional texts will change when confronted by the legitimate aspirations of autonomous citizens and groups," observing that "[s] uch a faith has survived even when aspirations ran contrary to ruling doctrines of constitutional law." Hendrik Hartog, The Constitution of Aspiration and "The Rights That Belong to Us All", 74 J. AM. HIST. 1013, 1014 
practices, including, but not limited to, Article $\mathrm{V}$ amendments.

The judge-centered framework in which Strauss and many other constitutional theorists describe our constitutional tradition obscures communicative pathways that connect judicial reasoning inside the courts to claims made about the Constitution by persons outside the courts. There are, of course, many such pathways in our constitutional system. Some are explicit elements of constitutional design, such as the Article $\mathrm{V}$ procedures for amendment, or the roles played by the legislative and executive branches in designing and staffing the court system and enforcing its decrees. Others have grown up in the interstices of these institutional arrangements. The rise of the party system is one such vehicle, and social movements are another.

Throughout American history, groups of Americans have mobilized to make interpretive and amendatory claims on the Constitution's text, yet constitutional theory rarely recognizes the role that social movements play in the construction of constitutional meaning. ${ }^{10}$ This omission is consequential, for if judges have played the central role in articulating constitutional norms in the American tradition, their understanding of the Constitution has been deeply shaped by mobilized citizenry, acting through electoral processes," and outside of them. ${ }^{12}$ In exploring the role of social movements in shaping constitutional meaning, this Article joins the small but rapidly growing body of constitutional theory written in law schools that examines the

(1987).

Akhil Amar quite self-consciously criticizes judicial interpretation of the Constitution within this tradition. As he put it recently, " $[w]$ hat the American People have said and done in the Constitution is often more edifying, inspiring, and sensible than what the Justices have said and done in the case law." Akhil Reed Amar, The Supreme Court, 1999 Term-Foreword: The Document and the Doctrine, 114 HARV. L. REv. 26, 27 (2000) (invoking the Constitution as a "document" as a basis for criticizing understandings of the Constitution contained in doctrine).

${ }^{10}$ Legal historians have documented the ways that social movements have endeavored to bring about constitutional reform, but very few constitutional theorists have addressed the role of social movements in the creation of constitutional meaning. But see infra note 14.

"See 2 Bruce Ackerman, We the People: Transformations 255-383 (1998) (analyzing the role played by electoral politics in reshaping constitutional jurisprudence of the New Deal Era).

${ }_{12}^{12}$ For some accounts of the ways that the labor movement has participated in shaping constitutional understandings, see William E. Forbath, Caste, Class, and Equal Citizenship, 98 MICH. L. REv. 1 (1999); and Drew D. Hansen, The Sit-Down Strikes and the Switch in Time, 46 WAYNE L. REv. 49 (2000). For some accounts of the ways that the modern civil rights movement has participated in shaping constitutional understandings, see infra note 38. 
life of the Constitution outside the courts. ${ }^{13}$

${ }^{13}$ Relatively little of this scholarship concerns social movements. One branch of the scholarship on the Constitution outside the courts criticizes judicial review in a variety of different frameworks. For example, Mark Tushnet has recently argued for a populist constitutionalism that involves the abolition of judicial supremacy. MARK Tushnet, TAKING THE Constitution AwAY From THE COURTS (1999). Cass Sunstein argues that judges should decide cases in accordance with an ethic of minimalism that would restrict the practical scope of judicial review without calling into question the Court's role as the ultimate expositor of the Constitution's meaning. CASS R. Sunstein, One Case at a Time: Judicial Minimalism on the Supreme Court 3-60 (1999). Akhil Amar, by contrast, cultivates a general skepticism about the Court's capacity to interpret the document in fidelity to its meaning and emphasizes that the Constitution is the People's. See, e.g., Amar, supra note 9 (contrasting the Constitution as "document" and "doctrine"). Along related lines, Jack Balkin and Sandy Levinson have argued for refashioning our constitutional canon so that it includes expositors of the Constitution speaking from positions outside the courts. J.M. Balkin \& Sanford Levinson, The Canons of Constitutional Law, 111 HARV. L. REV. 963, 1003-06 (1998); see also J.M. Balkin, Populism and Progressivism as Constitutional Categories, 104 YALE L.J. 1935, 1950 \& n.40 (1995) (discussing populist strains in American constitutional theory). For a thoughtful review of some of these trends in legal scholarship, see James E. Fleming, The Constitution Outside the Courts, 86 CORNELL L. REV. 215, 240-49 (2000), reviewing TUSHNET, supra.

Another and growing branch of scholarship explores the differences between legislative and judicial enforcement of the Constitution. Lawrence Sager has written several highly influential articles in this tradition. See, e.g., Lawrence Gene Sager, Fair Measure: The Legal Status of Underenforced Constitutional Norms, 91 HARV. L. REV. 1212 (1978) (arguing that elected officials may have different competence, authority, and obligation to enforce constitutional norms than do judges); Lawrence G. Sager, Justice in Plain Clothes: Reflections on the Thinness of Constitutional Law, 88 Nw. U. L. REV. 410, 435 (1993) (offering an account of our constitutional practice "in which we understand ourselves to be ... constitutionally obliged to address the injustice of poverty and entrenched racial disadvantage, but see the primary addressees of this obligation as elected officials rather than judges"). For more recent contributions exploring Congress's role in interpreting Section Five of the Fourteenth Amendment, see Evan H. Caminker, “Appropriate” Means-Ends Constraints on Section 5 Powers, 53 STAN. L. REV. 1127 (2001); and Robert C. Post \& Reva B. Siegel, Equal Protection By Law: Federal Antidiscrimination Legislation After Morrison and Kimel, 110 YALE L.J. 441 (2000). Larry Kramer examines the popular or democratic character of the American constitutional tradition in a rich historical account focused especially on its founding decades. Larry Kramer, The Supreme Court, 2000 Term-Foreword: We the Court, 115 HARV. L. REV. 4 (2001). For other historical discussions of these themes, see, for example, James Gray Pope, Republican Moments: The Role of Direct Popular Power in the American Constitutional Order, 139 U. PA. L. REV. 287, 325-44 (1990), discussing the founding; and Post \& Siegel, supra, at pts. III.C., IV.B, discussing the Warren Court era.

Finally, for literature exploring the concept of judicial supremacy itself, see Larry Alexander \& Frederick Schauer, On Extrajudicial Constitutional Interpretation, 110 HARV. L. REV. 1359 (1997); Neal Devins \& Louis Fisher, Judicial Exclusivity and Political Instability, 84 VA. L. REV. 83 (1998); Michael Stokes Paulsen, The Most Dangerous Branch: Executive Power to Say What the Law Is, 83 GEO. L.J. 217 (1994); Christopher L. Eisgruber, The Most Competent Branches: A Response to Professor Paulsen, 83 GEO. L.J. 347 (1994); and 
To date, the constitutional theorist most concerned about emphasizing the role of a mobilized citizenry in the making of constitutional law has been Bruce Ackerman. ${ }^{14}$ Ackerman has argued that courts can and should recognize constitutional amendments that do not satisfy Article $\mathrm{V}$ criteria, when judges discern mobilized majorities acting through the electoral process in patterns Ackerman calls constitutional moments. If judges tie constitutional interpretation to such electoral signaling, Ackerman argues, changes in judicial interpretation of the Constitution are appropriately anchored in values of popular sovereignty. ${ }^{15}$

Ackerman challenges the dichotomy between amendment and interpretation, and presents a rich account of constitutional change whose protagonists include elected officials as well as judges. But Ackerman's account continues to conceptualize social mobilization as an amendment analogue, a form of democratic lawmaking. Judges are justified in adopting new constitutional understandings when mobilized majorities achieve electoral victories that satisfy the rule of recognition Ackerman characterizes as a constitutional moment. ${ }^{16}$

This Article discusses the role of social movements in shaping constitutional meaning in a different framework. For present pur-

Mark Tushnet, Reflections on City of Boerne v. Flores: Tivo Versions of Judicial Supremacy, 39 WM. \& MARY L. REV. 945 (1998).

${ }^{14}$ See, e.g., 1 Bruce ACKERman, We the PeOPle: Foundations 19 (1991) [hereinafter 1 ACKERMAN] ("This country's Constitution focuses with special intensity on the rare moments when transformative movements earn broad and deep support for their initiatives."); 2 ACKERMAN, supra note 11, at 5 ("[T] he Constitution cannot be understood without recognizing that Americans have, time and time again, successfully repudiated large chunks of their past and transformed their higher law to express deep changes in their political identities.").

James Pope and William Forbath have chronicled the ways the labor movement has contested constitutional understandings. Their studies, written at the intersection of legal history and legal theory, represent an especially important account of constitutionalism from the standpoint of social movements. See, e.g., James Gray Pope, Labor's Constitution of Freedom, 106 YALE L.J. 941, 942 (1997) (presenting labor's constitution of freedom as a struggle for fundamental rights such as "the rights to organize, to assemble, to speak freely, and-above all-to strike"); Forbath, supra note 12, at 58-61 (describing the constitutional claims of early twentieth-century labor activists). Jules Lobel has explored the ways social movements have used aspirational litigation to challenge the courts' interpretation of the Constitution. See Jules Lobel, Losers, Fools E Prophets: Justice as Struggle, 80 CORNELL L. REV. 1331, 1332 (1995) ("Litigation may serve to legitimate a political movement, to publicize the issues raised by that movement, and perhaps to spur political action.").

${ }_{15} 1$ ACKERMAN, supra note 14.

${ }^{16}$ Id. 
poses, I am unconcerned with the question of whether the activities of a social movement amount to lawmaking that satisfies the Article V rule of recognition or the form of a constitutional moment. In contradistinction to Ackerman, I locate social movements in a framework of constitutional culture rather than constitutional lawmaking. By "constitutional culture" I refer to the network of understandings and practices that structure our constitutional tradition, including those that shape law but would not be recognized as "lawmaking" according to the legal system's own formal criteria. ${ }^{17}$

In this Article, I will be reflecting on the understandings and practices that empower nonjuridical actors to contest, and sometimes to reshape, authoritative understandings of our Constitution. Rather than examine these processes through the filter of the questionsShould a judge heed the claims of nonjuridical actors? Are these claims about constitutional meaning law?-this Article invites constitutional theory to develop more complex positive accounts of the practices through which nonjuridical actors participate in the production of constitutional meaning.

During periods of constitutional mobilization, citizens make claims about the Constitution's meaning in a wide variety of social settings. Sometimes such mobilizations result in constitutional amendments; most often they do not. But even when no formal act of lawmaking occurs, constitutional contestation nonetheless plays an important role in transforming understandings about the Constitution's meaning inside and outside the courts. If we liberate our account of constitutional change from frameworks that are concerned with determining whether lawmaking has occurred, we can give a richer account of the ways that debates about the Constitution outside the courts shape constitutional understandings inside the courts. Considered from this vantage point, dialogue between citizenry and judiciary about constitutional meaning is far more commonplace in our constitutional order than constitutional theory commonly acknowledges.

There are other ways that criteria concerned with constitutional lawmaking may unduly restrict our understanding of constitutional mobilizations. Lawmaking criteria filter out information concerning the ways that nonjuridical actors participate in constitutional change; lawmaking criteria also impose a particular structure on the ways we

\footnotetext{
${ }^{17}$ Infra text accompanying notes 55-72.
} 
understand the character of constitutional controversies. For example, it is common to characterize the purpose of constitutional amendments in instrumentalist terms, having in view the regulation of human conduct. ${ }^{18}$ So understood, the task of constitutional interpretation is to determine the nature of the constitutional constraints past generations have imposed upon us.

We certainly can read our constitutional development through the filter of such instrumentalist assumptions, but this way of proceeding will screen out much of what motivates citizens and elected officials to take positions in constitutional controversies. A closer look at the dynamics of constitutional mobilization and countermobilization suggests that the frameworks in which citizens reason about constitutional change are more complex than conventions for describing constitutional change generally recognize.

We can ignore or repress this complexity in order to adduce the decision rules that past generations of Americans have adopted to govern our lives. But imposing such a restrictive filter on the ways we understand constitutional change may not serve us well, given all the ways we reason about the past in the course of wrestling with questions of constitutional law. History matters in our constitutional culture, not merely because it is a source of constraint, but because it is a source of understanding that guides our judgments and gives them meaning. Given the many reasons we consult history in the course of reasoning about the Constitution's meaning, lawmaking criteria do not supply an adequate framework in which to describe constitutional mobilizations of times past.

This Article situates the question of constitutional change in a framework concerned with constitutional culture rather than constitutional lawmaking and calls for a thicker description of the understandings and practices through which mobilized groups of Americans regularly endeavor to shape the Constitution's meaning. In this account, the People's authority to speak to constitutional questions matters. Text and amendment matter, but not in the familiar lawmaking framework that Strauss criticizes. Yet if such a description of the ways that mobilized groups of citizens shape constitutional understandings will not conform in all particulars to familiar accounts of constitutional lawmaking, it may nonetheless be of internal significance to

\footnotetext{
${ }^{18}$ See, e.g., infra notes 49-52 and 73-74 (discussing this instrumentalist understanding of constitutional law).
} 
constitutional law.

Constitutional theory presupposes some model of jurisgenesis whenever it addresses the roles that judges, elected officials, and mobilized citizenry play in the creation of constitutional law. In an era when the role of judges was under sustained critical assault, constitutional theory devoted considerable efforts to exploring the practice of judicial review. Indeed, we can locate David Strauss's arguments for common law constitutionalism in this tradition. ${ }^{19}$

As the Supreme Court has most recently posed the question of judicial review, however, it has reoriented the question away from the countermajoritarian difficulty and the prerogative of judges to interpret the Constitution, and instead put in issue the prerogative of nonjuridical actors to participate in defining the Constitution's meaning. The Court is now sharply restricting Congress's power to enforce the Fourteenth Amendment, on the grounds that differences between legislative and judicial enforcement of the Constitution are an affront to judicial supremacy and the Court's power to say what the law is. ${ }^{20}$ In

19 For decades, the Supreme Court's critics have cautioned against judicial "lawmaking" in matters of constitutional adjudication, emphasizing that change through constitutional amendment is more democratic than change through constitutional interpretation. In these accounts, the Constitution's text and its amendment through Article V figure primarily as constraints on judges' discretion to interpret the Constitution. David Strauss is endeavoring to refute these traditions of reasoning about constitutional interpretation when he argues that text plays an insignificant role in constitutional interpretation and Article $\mathrm{V}$ is "irrelevant" as a mechanism of constitutional change. Strauss, Irrelevance, supra note 1, at 1459. For Strauss, adjudication is the paradigmatic form of constitutional lawmaking, and judicial interpretation is its core practice. His argument for common law constitutionalism advances, in provocatively strong form, understandings that now animate diverse accounts of judicial review.

Constitutional theorists commonly discuss the courts' obligation to read constitutional precedent in light of the evolving ethos of the nation. Yet in such accounts, courts engage in doctrinal and ethical modalities of interpretation, along with other modes of interpretation based on text, original understanding, and structure. See, e.g., PHILIP BOBBITT, CONSTITUTIONAL INTERPRETATION (1991) (analyzing how constitutional argument draws upon different modalities of constitutional interpretation). Strauss emphasizes the centrality of doctrinal and ethical argument in a way that sets him apart; he insists that arguments from text and original understanding do not, and should not, play a significant role in our constitutional tradition. In refusing to accord arguments from text and original understanding the usual deference, Strauss seems intent on liberating the practice of constitutional interpretation from the taint of illegitimacy critics of judicial review have bestowed upon it. Strauss, Common Law, supra note 3 , at 878-79.

${ }^{20}$ See City of Boerne v. Flores, 521 U.S. 507, 536 (1997) ("[T]he Constitution is preserved best when each part of the Government respects . . . the actions and determinations of the other branches. When the Court has interpreted the Constitution, it 
short, the Court has drawn into question the role that democratic bodies play in interpreting the Constitution. Under these circumstances, it is important to examine more closely how nonjuridical actors have participated in forging constitutional understandings we venerate today.

Who has authority to interpret the Constitution? One needs a positive account of the roles that different institutions and actors have played in shaping the Constitution's meaning before one can build a normative theory that defines relationships among institutions and actors who make conflicting claims about the Constitution's meaning. Developing a richer understanding of the dynamics of constitutional change sheds light on this question of constitutional interpretation and many others. Liberating our descriptive account of constitutional change from the constraints of lawmaking paradigms may make an important difference in the ways we understand the questions at stake in many chapters of our constitutional development, and, more generally, the practice of constitutional interpretation itself.

While this Article is organized as a rejoinder to Strauss's provocative thesis about the irrelevance of constitutional amendments, I have framed my argument in terms that reach beyond Strauss's thesis to engage assumptions that he shares with many other constitutional theorists. Strauss is hardly alone in modeling constitutional theory in terms that focus on the courts, that occlude pathways through which popular mobilizations help produce constitutional meaning, or that emphasize constitutional lawmaking as a framework for thinking about the dynamics of constitutional change. This Article thus builds a response to Strauss into a call for examining those aspects of constitutional theory that obscure the role that social movements play in shaping constitutional meaning.

Part I of this Article responds to Strauss's claims about the irrelevance of the ERA. Here I reflect on the significance that popular mo-

\footnotetext{
has acted within the province of the Judicial Branch, which embraces the duty to say what the law is."); see also Bd. of Trs. of Univ. of Ala. v. Garrett, 121 S. Ct. 955, 968 (2001) ("[T]o uphold the [Americans with Disabilities] Act's application to the states would allow Congress to rewrite the Fourteenth Amendment law laid down by the Court ....”); United States v. Morrison, 529 U.S. 598, 620 (2000) (declaring 42 U.S.C. $\$ 13981$, the civil rights remedy of the Violence Against Women Act, unconstitutional because "the Fourteenth Amendment place[s] certain limitations on the manner in which Congress may attack discriminatory conduct"). For discussion of the Court's new Section Five jurisprudence, see Caminker, supra note 13; Post \& Siegel, supra note 13 ; and infra text accompanying notes 114-132.
} 
bilization may have in the formation of constitutional law, even where such mobilization does not satisfy criteria for an Article V amendment. Part II of this Article explores different frameworks in which we might describe the relationship of law and society as we reason about the dynamics of constitutional change, and it illustrates how our account of constitutional change varies as we describe it from the standpoint of constitutional lawmaking and constitutional culture. Part III of this Article responds to Strauss's claims about the irrelevance of the Nineteenth Amendment. Here I consider how describing social movement challenges to entrenched constitutional understandings in a framework attentive to questions of constitutional culture rather than constitutional lawmaking may change the ways we reason about the meaning of an Article $\mathrm{V}$ amendment. The Conclusion considers how this account of the role that social movements play in shaping constitutional meaning can be brought to bear on disputes about the role of Congress and the Court in interpreting the Constitution.

\section{THE ORIGINS OF SEX DisCRIMINATION JURISPRUDENCE: COMMON LAW AND SOCIAL MOVEMENT PERSPECTIVES}

In The Irrelevance of Constitutional Amendments, Strauss invokes the rise of sex discrimination law to demonstrate that text plays an insignificant role in our constitutional tradition. As he observes, during the 1970s, the federal judiciary adopted a new understanding of the equal citizenship norm, even though the amendment proposing this understanding was never ratified:

Today, it is difficult to identify any respect in which constitutional law is different from what it would have been if the ERA had been adopted. For the last quarter-century, the Supreme Court has acted as if the Constitution contains a provision forbidding discrimination on the basis of gender. $^{21}$

For Strauss, the growth of modern sex discrimination law demonstrates the "irrelevance" of the ERA. ${ }^{22}$ Judges changed the way they interpreted the Constitution in response to the "developments in society" that prompted demands for a constitutional amendment, and this change in interpretation was appropriate, Strauss argues, even if the ERA was never formally ratified:

\footnotetext{
${ }^{21}$ Strauss, Irrelevance, supra note 1, at $1476-77$ (footnotes omitted).

22 Id. at 1477.
} 
[I] $t$ would be a mistake to say that an overly activist Court "ratified" the ERA in the face of a contrary verdict from the country. What "ratified" the ERA, in effect, was the same kind of thing that "ratified" the Child Labor Amendment: insistent pressure from society as a whole. In the case of the ERA, this took the form of the increasing presence of women in the workplace, in politics, and in other new roles. Instead of saying that the courts imposed an agenda on society, it is probably more accurate to say that the opposite occurred: because of developments in society, the Court would have found it very difficult to continue treating gender classifications as unproblematic. ${ }^{23}$

Strauss thus understands the rise of modern sex discrimination jurisprudence to demonstrate the peripheral significance of text in our constitutional tradition and of amendments in the dynamics of constitutional change.

But if we widen our angle of vision, we might view mobilization of women for constitutional change as the source of the new understanding that informed judicial interpretation of the Constitution in the 1970s. During the decade leading up to the Court's declaration that sex-based state action would be subject to heightened scrutiny under the Equal Protection Clause, groups coalesced around the goals of supporting or defeating the ERA and making claims about the meaning of the Fourteenth Amendment.

Speaking from a variety of social locations, Americans made claims about the Constitution that diverged from the ways that judges enforced its terms in the courts. These included claims about amending the Constitution (the ERA strategy), ${ }^{24}$ as well as claims about interpreting the Constitution (the Fourteenth Amendment strategy). ${ }^{25}$

${ }^{23}$ Id. at 1478 (footnotes omitted).

${ }^{24}$ The ERA was first introduced in 1923 by the National Women's Party (NWP); NWP lobbying ensured that the ERA was introduced in Congress every year thereafter and included in every Democratic and Republican platform beginning in 1944. MARY Frances BERRY, Why ERA FAILED: POLITICS, WOMEN's RIGHTS, AND THE AMENDING Process of the Constitution 44, 57 (1986); Jo Freeman, The Politics of Women's LIBERATION 63-64 (1975). For decades, women activists were divided about the advisability of the ERA, because the Amendment was thought to imperil protective labor legislation for women, but these concerns dissipated by the late 1960s. Women's groups persuaded Congress to include a prohibition against sex discrimination in Title VII of the Civil Rights Act of 1964 and then organized to secure its enforcement by the EEOC; soon thereafter judicial invalidation of protective labor legislation under Title VII made labor organizations' earlier opposition to the ERA moot. JANE J. MANS. BRIDGE, WHY WE LOST THE ERA 10 (1986); see also FREEMAN, supra, at 80-81 (observing that by 1969, the United Auto Workers had reversed their earlier opposition to the ERA).

${ }^{25}$ Beginning in the mid-1960s, feminist litigators were also beginning to invoke 
Claims about interpretation and amendment were initially advanced separately, and then often in tandem, ${ }^{26}$ by strategies that involved organizing outside the party system as well as in it; practices of litigation, lobbying, and legislation; techniques of mass mobilization and protest; and strategies of communication through the visual and print media. ${ }^{27}$

By 1970 , protests in support of the ERA had become widespread and visible in the media. As Susan Hartmann recounts:

[I]n August $1970 \ldots$ [o]n the fiftieth anniversary of women's suffrage, thousands of feminists of all persuasions responded to NOW's call for a Women's Strike for Equality. They marched, picketed, and held rallies across the country in the largest mass action for women's rights in the nation's history and the first demonstration of the new movement to receive serious and substantial press coverage. ${ }^{28}$

Protests escalated as ERA advocates sought to bring pressure to bear on Congress to enact the Amendment, and then to promote its ratification in statehouses across the nation. ${ }^{29}$ There was energetic opposi-

the Fourteenth Amendment as a constitutional ground for protecting women's rights. See Susan M. Hartmann, The Other Feminists: activists in the Liberal Es TABLISHMENT 60-91 (1998) (describing the early litigation campaigns of the ACLU Women's Rights Project); Serena Mayeri, "A Common Fate of Discrimination": RaceGender Analogies in Legal and Historical Perspective, 110 YALE L.J. 1045, 1069-79 (2001) (discussing Fourteenth Amendment litigation strategies from the mid-1960s to the mid-1970s).

${ }^{20}$ See Serena Mayeri, "We Differ Not So Much in Our Objectives As in Our Strategy": Pauli Murray and the Triumph of Strategic Feminist Constitutionalism, 19601972, at 21-28 (2001) (unpublished manuscript, on file with author) (discussing debates around the movement's interpretive and amendatory claims, and the strategic advantages and disadvantages in advancing them together).

${ }_{27}$ Supra notes 24, 25; infra note 29 and accompanying text.

${ }^{28}$ Susan hartmann, From Margin to Mainstream: american WOMEN AND POLITICS SINCE 1960, at 66 (1989).

${ }^{29}$ As part of the 1970 protests, the Pittsburgh chapter of NOW organized a protest that disrupted Senator Birch Bayh's hearings on the constitutional amendment for the eighteen-year-old vote. Bayh promised hearings on the ERA that began the next spring. FREEMAN, supra note 24, at 213; MANSBRIDGE, supra note 24, at 10-11. ERA supporters "generated millions of letters urging legislators to vote for the ERA. Fifteen hundred letters a month flooded some congressional offices." HARTMANN, supra note 28, at 105-06. After Congress approved the ERA on March 22, 1972, ERA supporters staged protests in a variety of states to promote the ratification of the Amendment. In 1972, ERA supporters in Virginia were arrested for disorderly conduct following the defeat of the Amendment in a House committee. BERRY, supra note 24, at 65-66. That same year, a California state senator who stalled the ERA in a committee faced constant demonstrations and interruptions at his public appearances until the Amendment made it out of the committee. Id. at 66 .

In this period, groups supporting the Amendment included: "a united AFL-CIO, the National Organization for Women, the National Federation of Business and Pro- 
tion to the ERA in Congress and in the nation in the period just before and after the Amendment's passage. ${ }^{30}$ But it was not until 1973, in the wake of the Court's decision in Roe $v$. Wade, ${ }^{31}$ that longtime Republican activist Phyllis Schlafly began a serious organizing drive against the ERA. ${ }^{32}$

fessional Women's Clubs, the General Federation of Women's Clubs, and Presbyterian, Baptist, Methodist, and Jewish federations." GILBERT Y. STEINER, CONSTITUTIONAL INEQUALITY: THE POLITICAL FORTUNES OF THE EQUAL RIGHTS AMENDMENT 46-47 (1985). Groups involved in ERAmerica, "a national alliance of over two hundred associations that supported [the] ERA, included the American Bar Association, the Girl Scouts, and the National Council of Senior Citizens." Id. at 47.

By early 1973, thirty states had ratified the Amendment with little legislative debate. MANSBRIDGE, supra note 24, at 12-13.

${ }^{30}$ Senator Samuel James Ervin, Jr., Democrat of North Carolina, led opposition to the ERA in the Senate. He defended traditionalist views of womanhood, claiming that the ERA was a "declaration of war on homemakers," would leave women unprotected in the workplace and would lead to such horrible results as integrated restrooms and women serving in combat. DONALD G. MATHEWS \& JANE SHERron DE HART, SEX, GENDER, AND THE POLITICS OF ERA: A STATE AND THE NATION 47-50 (1990).

At hearings on the ERA before the Judiciary Subcommittee, two scheduled witnesses testified against the ERA: Senator Ervin and a member of the National Council of Catholic Women. A surprise witness, testifying on behalf of the Justice Department, was William Rehnquist. Rehnquist began by affirming that "President Nixon and the Administration support the goal of establishing equal rights for women," before reading a twenty-nine page statement arguing against the need for a constitutional amendment. Rehnquist claimed that federal courts would further extend Fourteenth Amendment protection to women, and a constitutional amendment would sow confusion in this newly devleoping body of law. HUGH DAVIS GRAHAM, THE CIVIL RIGHTS ERA: ORIGINS AND DEVELOPMENT OF NATIONAL POLICY 1960-1972, at 416-17 (1990); see also BERRY, supra note 24, at 65 (noting that when the ERA was passed by Congress in 1972 , the party that nominated George Wallace for president in 1968 denounced the ERA as a "socialistic plan to destroy the home," while the politically conservative Happiness of Womanhood (HOW) group "insisted ERA would legitimate homosexuality and permit homosexuals to marry and even to adopt children").

Legal scholars also opposed the ERA. Paul Freund authored a statement against the ERA endorsed by forty-three lawyers and law school deans. Freund argued that the ERA would mandate an absolute standard of constitutional equality when in reality, he argued, women needed protection in a variety of social roles and settings. MATHEWS \& DE HART, supra, at 30.

31 U.S. 113 (1973).

32 After Congress passed the ERA in 1972 and Senator Ervin lost his Senate seat in 1974, Ervin teamed up with Phyllis Schlafly to oppose the ERA in the states. MATHEwS \& DE HART, supra note 30, at 50. Schlafly began a national "Stop ERA" campaign in 1973 that benefited from conservative evangelical and fundamentalist concern over the Supreme Court's decision in Roe v. Wade. BERRY, supra note 24, at 88-89. The New Right coalition that formed after 1973 included not only Republican stalwarts such as the American Party and the John Birch Society but also newly energized conservative religious groups, such as the National Council of Catholic Women and, later, Concerned Women for America. BERRY, supra note 24, at 65-66; FREEMAN, supra note 24, at 
Mobilization and countermobilization of groups that defined themselves around questions of constitutional reform changed the social and political landscape within which courts interpreted the Constitution. Lawmaking that satisfied the criteria of Article V never occurred, yet, over time, judges interpreting the Constitution in the midst of such social movement practices began to incorporate alternative understandings into their account of the Constitution.

Frontiero $v$. Richardson ${ }^{33}$ acknowledges that constitutional interpretation is taking place amidst such tumult. In the course of making the case for applying strict scrutiny to sex-based state action under the Equal Protection Clause, Justice Brennan's plurality opinion points to Congress's recent enactment of the ERA and employment discrimination statutes recognizing women's rights, ${ }^{34}$ while Justice Powell's concurring opinion argues against adopting the strict scrutiny framework on the grounds that the nation was in the midst of considering whether to ratify the ERA. ${ }^{35}$ Notwithstanding these reservations, three

217, 220; MANSBRIDGE, supra note 24, at 16, 143-48, 173-77. Traditional, often religious, persons saw ERA advocates as abortion supporters who "reject[ed] the notion that motherhood was a truly important task and endors[ed] sexual hedonism instead of moral restraint." MANSBRIDGE, supra note 24, at 13. The December 1974 headline in Schlafly's newsletter, "ERA Means Abortion and Population Shrinkage," connected these concerns. Id. at 223 n.28; see also Jane De Hart-Mathews \& Donald Mathews, The Cultural Politics of the ERA's Defeat, in RIGHTS OF PASSAGE: THE PAST AND FUTURE OF THE ERA 44, 48-51 (Joan Hoff-Wilson ed., 1986) (discussing anxieties about the ERA undermining "traditional" womanhood and blurring the roles of men and women in areas such as the military, sex crimes, abortion, integrated restrooms, homosexuality, and the family). This explosive coalition, combined with lackluster state organizations of ERA supporters, brought the ratification of the ERA to a near-halt. A few states rescinded their prior ratification, and only three states ratified the ERA in 1974, one state in 1975, and one state in 1977, for a total of thirty-five states. MANSBRIDGE, supra note 24 , at 13 . No states ratified the Amendment after 1977, even though Congress extended the original ratification deadline from 1979 to 1982 . Id.

${ }^{33} 411$ U.S. 677 (1973). For Strauss's account of the Supreme Court's deliberations in Frontiero, see Strauss, Irrelevance, supra note 1, at 1477.

34 Frontiero, 411 U.S. at 687.

95 Justice Powell believed the Court should exercise restraint in the ways it interpreted the Fourteenth Amendment while the Nation debated the ERA:

The Equal Rights Amendment, which if adopted will resolve the substance of this precise question, has been approved by the Congress and submitted for ratification by the States. If this Amendment is duly adopted, it will represent the will of the people accomplished in the manner prescribed by the Constitution. By acting prematurely and unnecessarily, as I view it, the Court has assumed a decisional responsibility at the very time when state legislatures, functioning within the traditional democractic process, are debating the proposed Amendment. It seems to me that this reaching out to pre-empt by judicial action a major political decision which is currently in process of resolution does 
years later, in the midst of the ratification debate, and with opposition to the Amendment beginning seriously to mobilize, ${ }^{3, j}$ a majority of the Court voted to adopt an intermediate scrutiny framework for sex discrimination claims under the Fourteenth Amendment. ${ }^{37}$

In adopting a new framework for reviewing sex discrimination claims under the Fourteenth Amendment, the Court was intervening in a wide-ranging controversy and responding to social movement activism in matters of women's rights, much as it developed modern race equality doctrine in the midst of impassioned national conflicts about segregation, and in response to the litigation, organizing, and protest activities of African Americans. ${ }^{38}$ Claims on the text of the

not reflect appropriate respect for duly prescribed legislative processes.

Id. at 692 (Powell, J., concurring).

sti See supra note 32 and accompanying text (discussing mounting opposition to the ERA by a number of political and religious groups).

${ }^{37}$ See Craig v. Boren, 429 U.S. 190, 197-99 (1976) ("[C]lassifications by gender must serve important governmental objectives and must be substantially related to achievement of those objectives.").

${ }^{38}$ For one account of the ways that the litigation efforts of the NAACP shaped modern equal protection doctrine, see RICHARD KLUGER, Simple JUSTICE: THE HISTORY OF BROWN $V$. BOARD OF EDUCATION AND BLACK AMERICA'S STRUGGLE FOR EQuality 545-81 (1976). See also ADAM FAIRClough, BetTer DAY COMING: BlaCkS AND EQUALITY, 1890-2000, at 82, 197-200, 218-19 (2001) (locating the NAACP's litigation campaign in a larger social movement history). Randall Kennedy has described how social movement protests orchestrated by Martin Luther King, Jr., shaped civil rights law of the Second Reconstruction:

King's activities placed him at or near the center of controversies that dramatically altered the nation's legal landscape. From the Montgomery Bus Boycott arose Cayle v. Browder, the Supreme Court decision that invalidated de jure segregation in intrastate transportation and thereby effectively overruled Plessy $v$. Fergusom. Protest campaigns in Birmingham and Selma constituted crucial links in the chain of events that culminated in the Civil Rights Act of 1964, the Voting Rights Act of 1965, and the Supreme Court decisions upholding these legislative initiatives.

These and related campaigns also gave rise to cases that significantly affected legal doctrines regulating freedom of expression.... The Civil Rights Movement ... stag[ed] protest activities that forced courts to create or refine doctrine involving a wide array of First Amendment concerns, including symbolic speech, the public forum, freedom of association, libel, and rules governing mass demonstrations.... The result was not only a beneficial transformation in the substantive law of race relations, but also a blossoming of libertarian themes in First Amendment jurisprudence.

Randall Kennedy, Martin Luther King's Constitution: A Legal History of the Montgomery Bus Boycolt, 98 YALE L.J. 999, 1000-01 (1989) (footnotes omitted). For an analysis of how the lunch counter sit-ins helped shape Warren Court case law concerning state action and congressional power under the Commerce Clause and Reconstruction Amendments, see Post \& Siegel, supra note 13, at 486-502. See also id. at 513-22 (discussing the 
Constitution made by mobilized groups of Americans outside " the courthouse helped bring into being the understandings that judges then read into the text of the Constitution. This process of constitutional jurisgenesis may not conform to the particulars of Article V, but neither is it adequately represented by the model of common law adjudication that Strauss invokes.

Strauss notes that constitutional lawmaking is proceeding in the midst of the ERA debate, but in an effort to defend the Burger Court from the charge of "activist" lawmaking, he takes pains to emphasize the immateriality of the failed ratification debate to the development of modern sex discrimination jurisprudence. ${ }^{9.9}$ Neither the "substantial support" for the ERA, nor opposition to it, is determinative on his account. ${ }^{40}$ Instead, Strauss depicts judicial interpretation of the Fourteenth Amendment as a response to "insistent pressure from society as a whole" that "took the form of the increasing presence of women in the workplace, in politics, and in other new roles. ${ }^{, 11}$ On his account, it was these changes in social structure that compelled the Court to change the way it was interpreting the Fourteenth Amendment and that justified the course the Court took.

Strauss's interest in defending the Court from the charge that it interpreted the Constitution in contravention of Article $\mathrm{V}$ may incline him to discount the role that popular debate about the Constitution played in the rise of sex discrimination jurisprudence. If Strauss defends the Burger Court from the charge that it acted in contravention of Article V, however, his deeper interest in the case of the ERA is to demonstrate the immateriality of Article $\mathrm{V}$ itself. As Strauss sees it, neither Article V nor the Constitution's text plays an important role in the dynamics of constitutional change in a "mature democratic society. ${ }^{, 42}$ As Strauss states his case:

When a regime is being established, formal texts are more important; the traditions, institutions, and understandings that bind a mature society together, and that make orderly change possible without formal amendments, are less well developed. But once a constitutional system has survived for, say, a generation or two, formal constitutional amendments of the kind Article $\mathrm{V}$ envisions become incidental to the main

democratic roots of modern sex and race equality jurisprudence).

${ }^{39}$ Strauss, Irrelevance, supra note 1, at 1476-78.

${ }^{40}$ Id. at 1477 .

11 Id. at 1478; see also supra text accompanying note 21 (quoting Strauss in full).

${ }^{42}$ Id. at 1460. 
processes of constitutional change. ${ }^{43}$

Strauss emphasizes that this claim is an extension of his argument that "the entire text of the Constitution (including the amendments) plays a limited role in the development of constitutional law in a mature democratic society."

By contrast, as I understand the rise of sex discrimination jurisprudence, both Article $\mathrm{V}$ and the text of the Constitution itself played an important role in the dynamics of constitutional change. Where Strauss sees judges interpreting precedent and tradition in light of "developments in society," I see this and more: judges interpreting the Constitution in the midst of a popular debate about the Constitution. Americans on both sides of the courthouse door are making claims about the Constitution. Outside the courthouse, the Constitution's text plays a significant role in eliciting and focusing normative disputes among Americans about women's rights under the Constitution-a dynamic that serves to communicate these newly crystallizing understandings and expectations about women's rights to judges interpreting the Constitution inside the courthouse door. Such communication occurs whether or not the activities in question satisfy Article V's rule of recognition for constitutional lawmaking.

These communications between citizenry and judiciary may not amount to Article V lawmaking, but they are nonetheless a regular and easily recognizable feature of our constitutional culture. In our constitutional culture, a variety of understandings and practices empower nonjuridical actors to challenge the way judges have interpreted the Constitution. Many of these understandings and activities focus on the Constitution's text.

Consider some of the understandings anchored by the Constitution's text. The terms of the constitutional compact are set forth in a writing, authored by "We the People." The Constitution's text proclaims the sovereignty of the People and has thus come to symbolize the Constitution's democratic authorship. The concept of the Constitution as text supports several interlocking understandings of authority in our constitutional tradition. Setting forth the terms of the constitutional compact in a writing signifies a commitment to transparency in government. The terms of government are to be open, accessible, contestable, and revisable. A constitutional order

\footnotetext{
I3 Id. at 1460-61 (footnotes omitted).

${ }^{44}$ Id. at 1461 n.8.
} 
organized on such terms allows for ongoing public authorship. It is as a document that the Constitution belongs to the polity and not merely to professionals, to the People and not to the state. ${ }^{45}$ The Constitution's text thus plays an important role in anchoring the understandings and practices that allow nonjuridical actors to contest the ways judges interpret the Constitution.

This cluster of symbolic meanings is to Strauss little more than that: a mythology that does not describe our constitutional practice. ${ }^{46}$ In a developed constitutional order, it is judges who make constitutional law by reasoning about social developments in light of constitutional precedent and traditions, and, Strauss concludes, judges do so rather well. ${ }^{47}$

But as the exchange over modern sex discrimination law illustrates, Strauss's "realism" about our constitutional tradition represents at best a highly stylized account of our constitutional development, in which judges have both the capacity and the inclination to divine changes in social norms as they evolve over time. Where Strauss sees judges reinterpreting precedent and tradition in light of "developments in society," I I see, amidst those "developments in society," citizens challenging the ways judges have interpreted the Constitution and engaged in conflict with each other about the meaning of the Constitution. Judges interpreting the Constitution are not simply responding to developments in society; they are responding to claims about the Constitution and intervening in ongoing social disputes about its meaning.

In times of constitutional mobilization, then, judges do not merely translate otherwise mute "social developments" into legality; rather, actors outside the courts are engaging in creative acts of constitutional interpretation, and judges interpret the Constitution while listening to the many social actors who are speaking about the Constitution's

45. See Philip Bobbitt, Constitutional Fate: Theory of The CONSTITUTion 26 (1982) (discussing Justice Hugo Black's understanding of the Constitution).

${ }^{46}$ See, e.g., Strauss, Common Law, supra note 3, at 879 ("[1]t is the common law approach, not the approach that connects law to an authoritative text, or an authoritative decision by the Framers or by 'we the people,' that best explains, and best justifies, American constitutional law today.").

${ }^{47}$ See $i d$. at 934 ("When we apotheosize the Framers we understate the importance of the many subsequent generations of lawyers and judges, and nonlawyers and nonjudges, who have helped develop the principles of American constitutional law.").

${ }_{48}$ Strauss, Irrelevance, supra note 1 , at 1478 , quoted in supra text accompanying note 23. 
meaning.

\section{INTERLUDE: REFLECTIONS ON THE LAW-SOCIETY RELATIONSHIP}

These two different stories about the rise of sex discrimination jurisprudence conceptualize the dynamics of legal change and the relation of law and society in quite different terms.

When Strauss discusses where constitutional law originates or how it exerts force, he focuses on the lawmaking activities of legal officials, imagined from a standpoint internal to the legal system. ${ }^{4 !}$ Judges make laws by consulting authoritative legal sources, yet they must do so in ways that are responsive to social developments if they expect to be able to enforce law. Law and society are thus sharply differentiated, yet tightly correlated. Law is a tool for regulating conduct ${ }^{50}$ that works only when it is adapted to the norms of the society it would regulate. $^{51}$ As Strauss models change, there is a high degree of norma-

4:) This is the standpoint from which Strauss makes his case about the irrelevance of the ERA. It is also the standpoint from which Strauss defends his claim that the Civil War Amendments "can be plausibly characterized as limited and incidental." Strauss, Irrelevance, supra note 1 , at 1486 . To substantiate this claim, Strauss discusses the ways state actors implemented the terms of the Civil War Amendments, barely acknowledging the conflicting understandings and expectations to which the amendments gave rise. Thus, he asserts that “ $[t]$ he practical effect of the Thirteenth Amendment was, at most, to abolish slavery only in the four border states ... that had not joined the Confederacy." $I d$. at 1480 . Similarly, he asserts that "[t]he Constitution, in practice, did not change with the [Fifteenth] Amendment. It changed only when deeper changes occurred in society." Id. at 1483 . Here, as in his account of the rise of sex discrimination jurisprudence, Strauss understands the dynamics of constitutional change through the lawmaking and law-enforcing activities of legal officials, and barely attends to the ways that citizens make competing claims about constitutional meaning. $C f$. $i d$. at 1484-85 ("Still, ... it might be said, when the civil rights revolution . . . did occur, it was important that the Fourteenth Amendment supplied a textual promise of equality to which advocates, and ultimately the Supreme Court, could point. But even this limited effect cannot be attributed to the Fourteenth Amendment without qualification."). Because Strauss analyzes law through the activities of legal officials, he does not attend to the claims that social movements make on the Constitution through litigation, lobbying, organizing, and protest, much less treat such claims as playing an important role in the dynamics of constitutional change.

${ }^{50}$ Infra text accompanying note 74.

${ }^{51}$ This understanding of the law-society relationship recurs throughout Strauss's argument. For example:

[F] or an amendment to matter, it must be unusually difficult to evade. An amendment that specifies a precise rule, for example, is more likely to have an effect than one that establishes only a relatively vague norm. If its text is at all imprecise, an arnendment that is adopted at the high-water mark of public sentiment will be prone to narrow construction or outright evasion once pub- 
tive coherence within law and society, as well as between them. ${ }^{52}$

Contrast Strauss's account, which imagines law and society as differentiated and instrumentally related systems, to another model of the law-society relationship, which recognizes that law is a network of institutions that can issue directives backed by sanctions, but also understands that law exerts authority as a system of meanings. Considered from this standpoint, the boundaries between law and society are considerably more difficult to demarcate. ${ }^{53}$ Through pathways of meaning, law can structure social life, even when there are no legal officials present to enforce the law. ${ }^{54}$ And it is through pathways of

lic sentiment recedes, as the Fourteenth and Fifteenth Amendments were. Strauss, Irrelevance, supra note 1 , at 1486.

${ }^{52}$ See id. at 1503 ("Sometimes amendments ratify a permanent shift in the political culture; sometimes they do not.... But in either event, what controls the pace of change is the culture, not the amendment."); see also id. at 1478 ("What 'ratified' the ERA, in effect, was the same kind of thing that ratified the Child Labor Amendment: insistent pressure from society as a whole."); $i d$. at 1479 ("But it was not the [Civil War] amendments that changed things. The amendments made relatively little difference when they were adopted; the changes they prescribed came about only when society itself changed.").

${ }^{53}$ In this context, it may be helpful to consider the distinction that Austin Sarat and Thomas R. Kearns draw between "instrumental" and "constitutive" perspectives on the law-and-society relationship. Austin Sarat \& Thomas R. Kearns, Beyond the Great Divide: Forms of Legal Scholarship and Everyday Life, in LAW IN EVERYDAY LIFE 21 (Austin Sarat \& Thomas R. Kearns eds., 1993). While instrumentalism "conceives of law as largely external to the social practices it regulates," the constitutive conception of law detects its effects "in meanings and self-understandings rather than in the results of sanctions." Id. at 27.

[T] hose who adopt the constitutive perspective believe that law permeates social life and that its influence is not adequately grasped when law is treated as an external, normative missile launched at independent, ongoing activities. ... We are not, as instrumentalists suggest, merely pushed and pulled by laws that impinge on us from the outside. Rather, we have internalized law's meanings and its representations of us, so much so that our own purposes and understandings can no longer be extricated from them.

Id. at 29. I join Sarat and Kearns in emphasizing that law exerts authority through pathways of meaning, but understand law as having significant institutional embodiment that the "constitutive" perspective may obscure. Cf. Austin D. Sarat, Redirecting Legal Scholarship in Law Schools, 12 YALE J.L. \& HUMAN. 129, 134 (2000) (reviewing Paul Kahn, The Cultural Study of LaW: Reconstructing legal Scholarship (1999)) ("The constitutive perspective contends that social life is run through with law, so much that the relevant category for the scholar is not the external one of causality ... but the internal one of meaning.").

${ }^{54}$ See, for example, Patricia EwICK \& Susan S. Silbey, The Common Place of LAW: STORIES FROM EVERYDAY LIFE 45 (1998), stating:

Every time a person interprets some event in terms of legal concepts or terminology-whether to applaud or to criticize, whether to appropriate or to re- 
meaning that all manner of social actors can shape law, ${ }^{5.5}$ even when no formal act of lawmaking transpires.

If we attend to these pathways of meaning, we will reason about many aspects of the law/society relationship differently, including the ways law changes. To determine how law changes, we might simply consult the legal system's official self-accountings and examine the conduct of those formally authorized to interpret and to enforce law; but the account this inquiry will generate is partial at best. We can supplement it by looking beyond the legal system's own account of lawmaking to legal culture-the network of understandings and practices in which a society's legal institutions are embedded. The understandings and practices that support a society's legal institutions are dispersed, involving a wide range of social actors in a wide range of contexts. Such understandings and practices may not be "law" or "lawmaking" according to the legal system's own formal criteria, but they play a regular part in the operations of the legal system, and so should be considered if we want to understand how law functions. By legal culture, then, I refer to those understandings and practices that give shape to a society's legal system, including but not limited to the formal procedures it designates as lawmaking.

sist-legality is produced. The production may include innovations as well as faithful replication. Either way, repreated invocation of the law sustains its capacity to comprise social relations.

See also, e.g., Robert W. Gordon, Critical Legal Histories, 36 STAN. L. REV. 57, 102-25 (1984) (illustrating how law and society are mutually constitutive); Reva B. Siegel, In the Eyes of the Law: Reflections on the Authority of Legal Discourse, in LAW'S STORIES: NARRATIVE AND Rhetoric IN THE LaW 225, 231 (Peter Brooks \& Paul Gewirtz eds., 1996) [hereinafter LAW'S STORIES] (arguing that law's role in shaping social understanding is far greater than the concept of "legal fictions" suggests).

${ }^{55}$ Austin Sarat observes:

[L] egal meanings are not simply invented and communicated in an unidirectional process.... Litigants, clients, and others bring their own understandings to bear; they deploy and use meanings strategically to advance interests and goals. They press their understandings in and on law and, in so doing, invite adaptation and change in the practices of judges, lawyers, and other legal officials.

Sarat, supra note 53, at 139.

${ }^{56}$ The legal system has criteria for determining what law is and when law changes. These criteria for recognizing "law" or "lawmaking" are generally developed for the purpose of regulating disputes about when judges (or other officers of the law) have authority to compel citizens, or other legal institutions, to act. But with a different set of purposes in view, one might give a different account of how and why law changes. This positive account might bear on questions that arise within the operations of the legal system, or outside of it. For present purposes, then, I defer the question of whether this account of legal culture is part of an "internal" or "external" understand- 
Strauss discounts the participation of nonjuridical actors in the rise of sex discrimination jurisprudence because their participation did not amount to lawmaking in the Article $\mathrm{V}$ sense. But if the social movement activities we have considered did not satisfy Article V criteria for constitutional lawmaking, these activities set up pathways of communication between the citizenry and judiciary that drew upon understandings and practices that are an entrenched feature of our constitutional culture.

To appreciate how our constitutional culture provides for such dialogue-even when it does not satisfy the legal system's official criteria for lawmaking-we can take a step back from the ways constitutional jurisprudence models the relations between citizenry and judiciary and describe that relationship from a different vantage point. This account will not assume that judges have authority to decide the meaning of the Constitution; rather, it will examine the understandings and practices that sustain the authority of officials to make and enforce law. Differently put, I am interested in exploring what we observe about the operations of the legal system when we don't assume that law is authoritative, but instead examine the understandings and practices that make law authoritative. These understandings and practices are integral parts of our constitutional culture, and as such, evolve in history; ${ }^{57}$ I invoke them here in broad outline only, for pur-

ing of the legal system. To this extent, I distinguish my discussion of legal culture from the work of Paul Kahn, who argues that we can apprehend a society's legal culture only be assuming a "non-participant" or external perspective on its legal system:

[T] he scholar of law's rule should not be asked whether law is the expression of the will of the popular sovereign and thus a form of self-government. These are propositions internal to the systems of belief. A scholarly discipline of the cultural form approaches these propositions not from the perspective of their validity, but from the perspective of the meaning they have for the individual within the community of belief.

Paul, KaHn, The Cultural Study Of LAw: Reconstructing Legal Scholarship 2-3 (1999).

${ }^{57}$ For example, Article $\mathrm{V}$ has existed as a lawmaking mechanism since ratification of the Constitution, but the frequency with which the nation has adopted amendments to the Constitution has varied considerably over its history. No amendments were ratified in the more than half-century between ratification of the Twelfth Amendment in 1804 and ratification of the Reconstruction amendments, with all their attendant procedural irregularities, in the aftermath of the Civil War. 2 ACKERMAN, supra note 11, at 99-119. Nearly another half-century passed until the nation ratified the Sixteenth Amendment in 1913, at the dawn of a stormy period of Progressive Era lawmaking. Four amendments, dealing with income tax, direct election of senators, temperance, and woman suffrage, were ratified between 1913 and 1920 , eliciting a storm of complaints that the Constitution was being amended too frequently, which culminated in 
poses of considering their relevance to constitutional theory.

What gives a judge authority to pronounce the Constitution's meaning? Consider some possibilities. Officials may hold authority through relations of fear, because members of a legal culture understand the sanctions that officials will inflict for disobedience. Officials can also hold authority through claims of right, because members of a legal culture believe that officials are entitled to exercise the power they have. The beliefs that confer authority on officials who make or enforce law may consist in little more than role recognition, coupled with a habit of deference to the judgment of "experts" about the content of the law. Or convictions about legitimacy may involve citizens more actively in making judgments about the laws officials are enforcing.

Democratic culture invites citizens to assume this more active role in forming judgments about the law. In this society, citizens are invited to form judgments, not only about the law made by their elected representatives, but also, as I have observed, about the Constitution itself. While the authority of the Constitution is sustained in part through practices of veneration and deference, it is also sustained through a very different kind of relationship, in which citizens know themselves as authorities, as authors of the law.

As we consider the range of understandings about authority in American constitutional culture, we can see that some conceptions of authority consolidate the power of officials in the legal system to declare the Constitution's meaning, while others enable challenges to such pronouncements. ${ }^{58}$ Given the mix of passive and active roles citizens assume in matters concerning the Constitution's meaning, some features of our constitutional culture work to legitimate institutions, while others work to support challenges to hegemonic understandings

the defeat of the child labor amendment and the campaign to repeal prohibition. DAVID E. KYVIG, EXPlicit AND AUTHENTIC ACTS: AMENDING THE U.S. ConstituTION, 1776-1995, at 193-267 (1996). Arguably, Article $V$ has not played the same role in negotiating culturally "hot" controversies since that time. Along similar lines, the Senate's advice and consent role in the appointment of Article III judges has its own history (in which Robert Bork occupies a special role), as do organized litigation strategies and social movement practices of protest and civil disobedience.

${ }_{58}$ Sandy Levinson calls these attitudes, respectively, Catholic and Protestant. See LEVINSON, supra note 9, at 29 ("As to the ultimate authority to interpret the source of doctrine, the protestant position is based on the legitimacy of individualized (or at least nonhierarchical communal) interpretation ..., while the catholic position is that the Supreme Court is the dispenser of ultimate interpretation ...."). 
and arrangements, enabling resistance in the name of right. ${ }^{59}$ Is the employment relationship free contract or wage slavery? Are citizens subject to government, or is government subject to citizens? Beliefs about the Constitution's democratic authorship authorize and empower citizens to make claims about the Constitution's meaning that diverge from the ways judges have interpreted it. The text of the Constitution thus elicits and channels dispute about the forms of freedom and unfreedom in American life.

Christopher Tomlins has emphasized that legal culture supports a plurality of understandings about right action, enabling the articulation of alternatives to officially recognized understandings:

Legal culture must be considered to encompass not only the discourse and practices of what is officially the law/legal system, or the discourse and practices that are responses to or invocations of that law/legal system, but also discourse and practices that represent other and very different constructions of what right action might look like. Understood in this way, legal culture represents a range of competing possibilities, a manifestation of the plurality of authorized behaviors and authorizing discourses existing in society at any one time, and of the relationships, complementary or antagonistic, among them.

${ }^{59}$ See, e.g, Hartog, supra note 9, at 1016-17 (“An American emancipatory tradition of constitutional meaning must be rooted in the subversive and disruptive and utopian messages that people read into constitutional texts and drew from diverse and contradictory sources ...."); see also id. at 1022 (discussing the ways that, in the United States, subordinated groups "have read into the Constitution an implied destabilization of those vested-and often constitutionally recognized-rights of others that constrained their capacities and their autonomy"). A number of critical race theorists have emphasized the power of rights discourse to support counter-hegemonic understandings of social relations. See, e.g., PAtricia J. Williams, The Alchemy of RaCE AND Rights 164 (1991) ("Rights feel new in the mouths of most black people ... . It is the magic word of visibility and invisibility, of inclusion and exclusion, of power and no power. The concept of rights, both positive and negative, is the marker of our citizenship, our relation to others."); Mari J. Matsuda, Looking to the Bottom: Critical Legal Studies and Reparations, 22 HARV. C.R.-C.L. L. REV. 323, 333 (1987) ("The dissonance of combining deep criticism of law with an aspirational vision of law is part of the experience of people of color."); Pope, supra note 14, at 953 ("Rights claims now play a vital role in the "cognitive liberation' of social movements from fatalism."); cf. Alan Hunt, Rights and Social Movements: Counter-Hegemonic Strategies, 17 J.L. SoC'Y 309, 313 (1990) (“[C]ounterhegemony... has to start from that which exists, which involves starting from 'where people are at.' Such a conception of counter-hegemony requires the 'reworking' or 'refashioning' of the elements which are constitutive of the prevailing hegemony.").

${ }^{60}$ Christopher Tomlins, Subordination, Authority, Law: Subjects in Labor History, 47 INT'L. LAB. \& WORKING-CLASS HIST. 56, 66-67 (1995). James Pope draws on Robert Cover's theory of jurisgenesis to explore the ways social movements can participate in making constitutional meaning. 
In this society, mobilized groups of citizens understand themselves as authorized to speak to matters involving "what is officially the law/legal system" where the Constitution is concerned, in a way that they do not feel authorized to speak about questions of tort or property law. Of course, at any point in time, those subject to the common law may resist, evade, and contest its terms, but understandings about the authorship of the Constitution empower citizens to voice objections to official declarations of constitutional law in special ways.

When mobilized groups of citizens make interpretive or amendatory claims on the text of the Constitution, they do so with the understanding that they are authorized to do so and with the expectation that law might in fact change by reason of their claims. This expectation that law is semantically permeable distinguishes ways people respond to "official" declarations about the meaning of the Constitution and the common law. Of course, authority to speak about matters concerning the Constitution is not distributed equally throughout society, nor do individuals or groups experience it consistently. But the understanding that the Constitution is the People's gives rise to a distinct, and historically evolving, set of attitudes and practices that provoke, sustain, and support popular engagement with constitutional law. These historically evolving attitudes and practices in turn play an important role in shaping official declarations about the Constitution's meaning.

Because our constitutional culture addresses ordinary citizens as authors and imbues them with the expectation that official declarations of the law are semantically permeable, contestable, and revisable, official pronouncements about the meaning of the Constitution elicit special forms of engagement from citizens and so become a focal point of normative contestation.

Beliefs about the Constitution's authority as law shape the discursive structure of such conflicts. Ordinary citizens believe that they are entitled to make claims about the meaning of the Constitution, while at the same time they view the Constitution as a form of paramount

Robert Cover's concept of jurisgenesis, the creation of legal meaning, provides the foundation for a theory about the role of legal thought and practice in sustaining resistance, and thus for an ideal type of constitutional insurgency that proceeds from localities to the center. ... [U]nlike the traditional concept of jurisprudence, which envisions legal thought as a science ...., jurisgenesis is a cultural process that occurs in a wide range of social settings, many of them outside official legal institutions.

Pope, supra note 14, at 954 (footnote omitted). 
law that supervenes ordinary expressions of political will. Thus, it is not by proclaiming the semantic indeterminacy of the Constitution that citizens make claims-to courts or each other-about the Constitution's meaning, but something like the contrary. Citizens invoke the text of the Constitution, properly interpreted or amended in light of our constitutional traditions, as a foundation, having meaning that can be ascertained apart from the pronouncements of those authorized to interpret it or the preferences of those who live under it.

Sometimes citizen claims are interpretive and take the form of an assertion about what the Constitution does say; sometimes these claims are amendatory and take the form of an assertion about what the Constitution ought to say. During periods of social movement mobilization, interpretive and amendatory claims are often advanced in tandem, ${ }^{61}$ and there are certain deep linkages between them. Citizens advancing amendatory claims appeal to the understandings constituting our constitutional tradition to challenge "official" declarations about the Constitution's meaning, and as they do so, amendatory claims may converge with interpretive claims in semantic structure. $^{62}$

a) During the nineteenth century and the twentieth century, the women's movement has gone through periods in which it forged new constitutional understandings by advancing interpretive and amendatory claims on the Constitution simultaneously. See supra text accompanying notes 26-27 (discussing Fourteenth Amendment and ERA claims); infra text accompanying notes 89-92 (discussing Fourteenth Amendment and suffrage amendment claims).

${ }_{62}$ Although there are few formal restrictions on the exercise of the Article $\mathrm{V}$ amending power, longstanding traditions of argument in our constitutional culture seem to channel debates about whether to exercise Article V power into debates about whether the proposed amendment comports with understandings constituting our constitutional tradition. One could argue for or against an amendment by insisting that it is important to change our constitutional tradition, but habits of appealing to the Constitution as a form of foundational law seem to undermine the persuasive force of such an appeal. Advocates advancing arguments for constitutional lawmaking often make their case by appeal to foundational understandings of the Constitution, just as their opponents will appeal to foundational understandings of the Constitution to oppose them-sometimes even arguing that certain exercises of the Article $\mathrm{V}$ power are unconstitutional. See, e.g., Clement E. VOSE, Constitutional Change: AMENDMENT POLITICS AND SUPREME COURT LITIGATION SinCE 1900, at 39-63 (1972) (discussing law review articles and litigation during the Progressive Era that advanced the claim that the Fifteenth and Nineteenth Amendments were unconstitutional).

Just as some traditions of argument about constitutional amendment resemble forms of constitutional interpretation, there are forms of constitututional interpretation that diverge so far from prevailing understandings of the Constitution that they have affinities to amendatory claims. See Lobel, supra note 14, at 1331-33 (discussing aspirational social movement litigation that proposes alternative constitutional under- 
Citizens advancing claims about the Constitution's meaning address legal authorities and each other, often speaking in groups. The lawmaking apparatus of Article $V$ has no doubt served as an impetus to group organizing around questions of constitutional law, for the possibility of changing the Constitution's meaning through constitutional lawmaking stimulates citizens to articulate grievances about constitutional interpretation to each other and not merely to the Court. Beliefs about the Constitution as foundational law play a role here as well. One cannot appeal to the Constitution as meaning something other than what legal authorities say without persuading other members of the community that one's claim about the meaning of the Constitution is correct.

Struggles over the Constitution are conducted in many social settings, through a wide variety of institutional pathways and practices. Groups speak through the electoral process and the party system, whether by petitioning, voting, or convening to address their representatives in legislative hearings concerning constitutional amendments or judicial appointments. Perhaps just as commonly, groups endeavor to address constitutional questions by resort to channels of communication outside the electoral process. Most prominently, citizens organize to secure constitutional amendments. But they also engage in litigation and employ various repertoires of protest (conventions, marches, civil disobedience) in the effort to communicate and legitimate alternative understandings of the Constitution. Typically, one group exercises multiple avenues of communication simultaneously as it endeavors to shape public understanding-the judgments of lawmakers and citizenry alike.

As groups make claims that the Constitution, as foundational law, speaks to various controversies, they elaborate the Constitution's meaning with respect to different institutions and practices and so continually refresh the text's normative ambit. Thus, the abolitionist movement tied the Guarantee Clause to slavery, ${ }^{63}$ while the women's movement tied it to voting. ${ }^{64}$ The Thirteenth Amendment's prohibi-

standings decades before the nation is ready to entertain them as plausible constructions of the Constitution's meaning). (1988).

${ }^{63}$ ERIC FONER, RECONSTRUCTION: AMERICA'S UNFINISHED REVOLUTION 232-33

${ }^{134}$ See Reva B. Siegel, She the People: The Nineteenth Amendment, Sex Equality, Federalism, and the Family, 115 HARV. L. REV. (forthcoming 2002) (Sept. 4, 2001, manuscript at 45-51, on file with the University of Pennsylvania Law Review). 
tion on slavery has been the focal point of protests about work, segregation, and marriage. ${ }^{65}$ Over the life of the republic, groups have sought constitutional amendments that would nationalize family law in order to restrict divorce, ${ }^{66}$ outlaw child labor, ${ }^{67}$ or prohibit same-sex marriages. ${ }^{68}$ The groups that organized for and against the woman's suffrage and equal rights amendments also struggled over the ideal forms of family life, ${ }^{69}$ as I develop in more detail below.

${ }^{65}$ See Risa L. Goluboff, The Thirteenth Amendment and the Lost Origins of Civil Rights, 50 DUKE L.J. 1609, 1637-79 (2001) (discussing the rediscovery and reconstruction of the Thirteenth Amendment as a means of vindicating and framing civil rights in the 1940s); Lea S. Vandervelde, The Labor Vision of the Thirteenth Amendment, 138 U. PA. L. REV. 437, 475-95 (1989) (considering labor movement arguments that the Thirteenth Amendment addressed, in addition to slavery, the working conditions of former slaves); Joan G. Zimmerman, The Jurispmudence of Equality: The Women's Minimum Wage, the First Equal Rights Amendment, and Adkins v. Children's Hospital, 1905-1923, 78 J. AM. HIST, 188, 211 (1991) (discussing an early draft of the ERA, introduced in the 1920s, that was modeled on the Thirteenth Amendment and declared: "Neither political nor legal disabilities on account of sex or coverture shall exist within the United States or any place subject to its jurisdiction" and " $t]$ he idea lingering behind the use of the Thirteenth Amendment model was that marriage under the common law was a form of involuntary servitude for women").

60 Various groups seeking to restrict divorce proposed constitutional amendments that would give the federal government power to enact uniform marriage and divorce legislation. For some accounts, see NELSON MANFRED BLAKE, THE ROAD TO RENO: A HISTORY OF DIVORCE IN THE UNITED STATES 130-51 (1962); and William L. O'NeILL, DIVORCE IN THE PROGRESSIVE ERA 238-61 (1967).

${ }^{67}$ On the child labor amendment proposed in the early 1920s, see Bill Kauffman, The Child Labor Amendment Debate; or, Catholics and Mugwumps and Farmers, $10 \mathrm{~J}$. LIBERTARIAN STUD. 139 (1992); and Richard B. Sherman, The Rejection of the Child Labor Amendment, 45 MID-AMERICA 3, 3-13 (1963).

${ }^{68}$ The cover page of a recent issue of the National Review proposes a constitutional amendment providing that " $[\mathrm{m}]$ arriage in the United States shall consist only of the union of a man and a woman," on the grounds that "[o]nly an amendment to the Constitution can end the abuse of the judicial process and protect both marriage and democracy in America." NAT'L REV., July 23, 2001, at cover; see also The Constitution: In Need of Amendment, NAT'L REV., July 23, 2001, at 16 (arguing that there should be a constitutional amendment prohibiting gay marriage in order to thwart a perceived "judicial campaign" to "override the wishes of the people"); Carey Goldberg, Quiet Anniversary for Civil Unions, N.Y. TIMES, July 31, 2001, at A14 (discussing the efforts of a national group, Alliance for Marriage, to secure a federal constitutional amendment defining marriage as a union between a man and a woman). Such amendments are already being ratified as part of state constitutions. For an analysis of social movement mobilization and countermobilization to secure state constitutional amendments that prohibit or allow same-sex marriage, see Douglas S. Reed, Popular Constitutionalism: Toward a Theory of State Constitutional Meanings, 30 RuTGERS L.J. 871, 901-31 (1999).

69) See supra note 30 and accompanying text (discussing debates surrounding attempts to pass the ERA); infra text accompanying notes 96-104 (considering debates over woman's suffrage). 
Just as the language of the Constitution acquires meaning as it is drawn into new conflicts, constitutional argument can transform the conflicts into which it is drawn. To make arguments about how the Constitution, properly interpreted or amended, bears on particular controversies, advocates frame the conflict in light of constitutional values and the narratives understood to vindicate those values. The conflict is thereby articulated in ways that invoke competing understandings of the nation's identity, memories, obligations, commitments, and ends. ${ }^{70}$ Interpretive reframing of conflict is further accelerated as groups recruit and mobilize members: a process that requires continual elaboration of the reasons why existing constitutional understandings and arrangements inflict harm."

Through such understandings and practices, all manner of social conflicts are channeled into struggles over the Constitution's meaning, and the Constitution comes to serve as a discursive medium through which individuals and groups engage in disputes about the ideal forms of collective life.

As a general matter, constitutional theory models the making of constitutional law in terms that do not notice, much less count as significant, the understandings and practices that I have been sketching. Strauss presents this generally unarticulated consensus in unusually strong form when he argues that group mobilization is not relevant to questions of constitutional law. ${ }^{72}$

Strauss contends that in a mature constitutional democracy, amendments are usually "irrelevan[t]" as a vehicle of constitutional change, and so he concludes that organizing for constitutional amendments is generally "a mistake":

If amendments are in fact a sidelight, then it will usually be a mistake for people concerned about an issue to try to address it by amending the Constitution. Their resources are generally better spent on legislation, litigation, or private-sector activities. It is true that the effort to obtain a constitutional amendment may serve very effectively as a rallying point

${ }^{70}$ For some accounts that explore the role of narrative in legal reason, see ANTHONY G. AMSTERDAM \& JEROME BRUNER, MINDING THE LAW 110-64 (2000); L.H. LARUE, CONSTITUTIONAL LAW AS Fiction: NARRATIVE IN THE RHETORIC OF AUTHORTY (1995); and LAW's STORIES, supra note 54.

${ }^{71}$ See infra text accompanying note 74 (discussing the role that interpretation plays in the dynamics of social movement mobilization).

${ }^{72}$ Cf. supra note 19 and accompanying text (discussing the ways Strauss converges with and diverges from other constitutional theorists in advancing his argument for common law constitutionalism). 
for political activity. A constitutional amendment may be an especially powerful symbol, and it may be worthwhile for a group to seek an amendment for just that reason. But in this respect constitutional amendments are comparable to congressional resolutions, presidential proclamations, or declarations of national holidays. If they bring about change, they do so because of their symbolic value, not because of their operative legal effect.

Strauss acknowledges that a constitutional amendment can be a rallying point for political activity. But to the extent a constitutional amendment has such effects, Strauss emphasizes it is functioning symbolically, like the declaration of a national holiday, and not exerting force as law. On this account, law would appear to exert force instrumentally, not expressively-coercively, not semantically.

Is such a distinction intelligible? It is in fact difficult to distinguish the "symbolic value" of a constitutional amendment from its "operative legal effect," as Strauss suggests we ought. Even if one imagines law exerting force in the form of directives backed by sanctions as Strauss seems to do when he distinguishes the "operative legal effect" of a constitutional amendment from "congressional resolutions, presidential proclamations, or declarations of national holidays," law's efficacy as a tool for regulating conduct would still seem to depend on pathways of understanding. Perhaps Strauss is emphasizing that what makes "law" is its coercive force, its power to shape behavior through threat of sanctions; and that, therefore, what motivates groups to mobilize for law reform (as distinct from seeking the declaration of a presidential holiday) is the objective of managing social life through the manipulation of such sanctions.

But social change is effectuated through the contestation of meanings, not merely the manipulation of sanctions, as groups organizing for constitutional reform over the life of the republic have long known. Reasoning about our constitutional tradition through the filter of instrumentalist assumptions that Strauss brings to the question will systematically exclude much of what motivates Americans-on and off the bench-to assume positions in constitutional controversies. $^{74}$

${ }^{73}$ Strauss, Irrelevance, supra note 1, at 1467 (emphasis added).

${ }^{74}$ There is now a growing body of literature devoted to exploring the ways that expressivist concerns animate bodies of law that are justified on consequentialist or instrumentalist grounds. As Elizabeth Anderson and Richard Pildes observe:

[E]ven where rhetorical structures of justification in judicial opinions invoke consequentialist (or functional or instrumental) language, the patterns of decision are best understood in expressive terms. Just as public discourse over 
In discussing whether Americans should mobilize for constitutional amendments, Strauss does not present himself as arguing for a particular approach to interpreting constitutional amendments, but instead as analyzing their efficacy in our constitutional order, from the standpoint of a sophisticated and frank kind of legal realism. But his argument for the irrelevance of constitutional amendments, and the immateriality to constitutional law of the organizing activities that bring them into being, illuminates certain assumptions about how constitutions are law that deeply shape the interpretive practices through which we adduce constitutional meaning. After all, the "operative legal effect" of a constitutional amendment does not inhere in the constitutional amendment. An amendment acquires its meaning through practices of interpretation that in turn presuppose certain understandings of what it means to have a constitution. To restate this point more concretely: The ways we imagine the making of law may well affect the ways we understand the meaning of law.

How might the ways we reason about the dynamics of constitutional change affect the ways we interpret Article $\mathrm{V}$ amendments? I explore this question below, as I consider Strauss's argument for the "irrelevance" of the Nineteenth Amendment.

\section{THE "IRRELEVANCE" OF THE NINETEENTH AMENDMENT: REFLECTIONS ON SOME WAYS A SOCIAL MOVEMENT PERSPECTIVE MIGHT INFORM CONSTITUTIONAL INTERPRETATION}

The Nineteenth Amendment was ratified, whereas the ERA was not; Strauss thus rests the case for its irrelevance on somewhat distinct grounds. Rather than argue that constitutional law changed without resort to Article $\mathrm{V}$ processes, he argues that the same legal changes could have been accomplished within just a few years without resorting to Article $\mathrm{V}$ processes. Reviewing the progress of the campaign in the Progressive Era, Strauss reasons that "a state-by-state campaign for

certain policy issues is often carried out in consequentialist language despite the fact that people's views appear actually rooted in expressive considerations, so too do modern Supreme Court constitutional decisions often cloak expressive considerations in non-expressive terms.

Elizabeth S. Anderson \& Richard H. Pildes, Expressivist Theories of Law: A General Restatement, 148 U. PA. L. REV. 1503, 1532 (2000) (footnote omitted). For an influential analysis of this dynamic in criminal law, see Dan M. Kahan, The Secret Ambition of Deter-
rence, 113 HARV. L. REV. 413 (1999). 
women's suffrage might also have succeeded"75:

The Nineteenth Amendment certainly suppressed outliers; it made women's suffrage uniform before it otherwise would have been. Beyond that, probably the best estimate is that if the suffragists had been forced to concentrate solely on the state level, they would have achieved substantial but not complete success within a few years.

Strauss asserts the superfluity of Article $\mathrm{V}$ processes on several grounds. On the one hand, he emphasizes that the availability of state legislative fora diminished the significance of the Constitution as a source of law for enfranchising women. The movement could have accomplished its goal by other means, even if it might have taken more organizing work and so briefly delayed the movement's ultimate victory. But Strauss's argument for the irrelevance of the Nineteenth Amendment involves an additional and analytically distinct claim. Strauss asserts that society's political norms had already changed in favor of women voting by the time of ratification, and so resorting to constitutional lawmaking played no significant role in forging the change in political culture favoring recognition of women's right to vote:

The Nineteenth Amendment is revealing in other ways about the limited role of the formal amendment process in bringing about constitutional change. A naive reader of the text of the Constitution would think that racial minorities have voted since 1870 and that women have voted since 1920. That is true of women-there is no evidence of systematic subversion of the Nineteenth Amendment-but emphatically untrue of African-Americans. By 1920, American society really had changed to the point that it was willing to accept (and even insist on) women's suffrage.... Sometimes amendments ratify a permanent shift in the political culture; sometimes they do not. The lack of resistance to the enforcement of the Nineteenth Amendment reveals that it fell into the former category. But in either event, what controls the pace of change is the culture, not the amendment.

When Strauss asks about the importance of enfranchising women under the Federal Constitution, he presumes that a consensus to enfranchise women has formed in "political culture" that can be enforced through an act of lawmaking, whether under federal or state law. For Strauss, it is a matter of indifference whether this consensus is en-

\footnotetext{
${ }^{75}$ Strauss, Irrelevance, supra note 1, at 1502.

${ }^{70}$ Id. at $1502-03$.

${ }^{77} I d$. at 1503 (emphasis added).
} 
forced through federal or state law; Article V, on his account, is a lawmaking tool like any other. ${ }^{78}$

Strauss explicitly carries this account of constitution making into a claim about constitutional meaning. Strauss argues that because Article $\mathrm{V}$ is a lawmaking tool like any other, Article $\mathrm{V}$ amendments, such as the Nineteenth Amendment, should play no special role in the ways we interpret any other provision of the Constitution:

These arguments [for synthetic interpretation] presuppose that amending the Constitution-and, by implication, failing to amend the Constitution-is a significant event. If this supposition is true, a formal, textual amendment might legitimately be read back into other provisions of the Constitution to produce a result that would not be warranted without the formal amendment. But if the amendments carry no special significance-if they are not the principal means (or even an important means) by which the People change our constitutional order-then these interpretive approaches lose their foundation. It may be correct to interpret the Fourteenth Amendment to forbid gender discrimination, and the movement toward greater equality for women, including women's suffrage, may be a legitimate reason to interpret the Fourteenth Amendment this way. But the fact that women's suffrage was formally recognized by the Nineteenth Amendment-instead of coming about through, for example, state legislation or judicial interpretationshould not carry great weight. ${ }^{79}$

Strauss argues that because constitutional reform through Article $\mathrm{V}$ resembles ordinary acts of lawmaking, we should not consider the Constitution's subsequent amendment as we interpret its earlier enacted provisions. Women could have secured the right to vote by diverse legal means, so there is no reason to pay special attention to ratification of the Nineteenth Amendment as we interpret older provisions of the Constitution, such as the Fourteenth Amendment's Equal Protection Clause.

In what follows, I want to show how a particularly restricted picture of constitutional lawmaking as an instrumental activity shapes the ways Strauss reasons about the Nineteenth Amendment, and to suggest how analyzing the Amendment from a social movement standpoint-and from a standpoint of constitutional culture rather than

${ }^{78} I d$. at $1502-03$.

${ }^{79}$ Id. at 1467 (footnotes omitted); see also id. at 1466 (observing that "[o] thers have invoked the Nineteenth Amendment, which guarantees women's suffrage, as a reason for interpreting the Fourteenth Amendment to forbid gender discrimination across the board" and remarking that such "an interpretation of the Fourteenth Amendment ... appears inconsistent with the original understanding of that provision"). 
constitutional lawmaking-might alter the way we understand it today. In other words, I will be considering how the frameworks in which we analyze constitutional change shape the ways we understand the meaning of an Article $\mathrm{V}$ amendment.

Many constitutional lawyers would find provocative Strauss's claim about the irrelevance of constitutional amendments, but few would invoke the Nineteenth Amendment as a ground on which to contest it. In my experience, few constitutional lawyers even know "which one" the Nineteenth Amendment is. We read the Nineteenth Amendment as a nondiscrimination rule concerning voting with which we now comply, and so we treat it as Strauss suggests we ought: as a matter of constitutional irrelevance. I have elsewhere argued that we read the Amendment as irrelevant because we read it shorn of any semantically informing context, ${ }^{80}$ but would like here to demonstrate how instrumentalist assumptions about an amendment of the sort Strauss articulates also play an important role in restricting its meaning.

To begin discussion of this question, I want to establish that there are alternatives to reading the Nineteenth Amendment as Strauss and most literate constitutional lawyers do: that is, as a nondiscrimination rule that only concerns voting. One alternative interpretive framework is to read the Amendment in light of the norms and understandings that animated its passage. Akhil Amar, for example, reads the Nineteenth Amendment as embracing a certain background understanding of civil and political rights; he contends that the Amendment, properly interpreted, should protect women's right to serve in office and on juries. $^{81}$

${ }^{80}$ Reva B. Siegel, Collective Memory and the Nineteenth Amendment: Reasoning About "the Woman Question" in the Discourse of Sex Discrimination, in HISTORY, MEMORY, AND THE LAW 131, 133 (Austin Sarat \& Thomas R. Kearnes eds., 1999).

81 See AKHIL ReEd AMAR, THE BILl OF Rights: CREATION AND RECONSTRUCTION 274 (1998) (arguing that the Fifteenth and Nineteenth Amendments should be read together to guarantee women the right to serve on juries); Akhil Reed Amar, The Bill of Rights as $a$ Constitution, 100 YALE L.J. 1131, 1202-03 (1991) (suggesting that the Nineteenth Amendment's sex-equality principle might apply to political rights so that it would have implications for military and jury service); Akhil Reed Amar, Women and the Constitution, 18 HARV. J.L. \& PUB. POL'Y 465, 471-72 (1995) (arguing that the Nineteenth Amendment stands for "full rights of political participation" for women, in addition to voting rights). For another argument that the Nineteenth Amendment bears on conduct other than voting, see Sarah B. Lawsky, Note, A Nineteenth Amendment Defense of the Violence Against Women Act, 109 YALE L.J. 783 (2000), arguing that the Violence Against Women Act of 1994 is valid legislation under the Nineteenth Amendment. 
We could take another step and read the inclusion of the Nineteenth Amendment in the Constitution as having implications for diverse bodies of constitutional law. In the immediate aftermath of ratification, the Supreme Court drew on both these modes of interpretation-historical and synthetic-to strike down a sex-based minimum wage law in Adkins v. Children's Hospital, ${ }^{82}$ reasoning that the gender understandings of substantive due process doctrine under the Fourteenth Amendment changed with the ratification of the Nineteenth Amendment. ${ }^{83}$ Recently, I have also drawn on historical and synthetic modes of interpretation to argue that we ought to read the Nineteenth Amendment in light of the debates about sex equality, federalism, and the family that led to its ratification, and, with this understanding, to read the Fourteenth and Nineteenth Amendments together as empowering Congress to enact laws securing women equality in family life. ${ }^{84}$ On this account, the debate over whether women should be enfranchised under the Constitution, which lasted from the Reconstruction to the Progressive Era, constitutes an important, and totally neglected, chapter in the history and traditions of "our federalism."

This Article is not the place to pursue alternative interpretations of the Nineteenth Amendment in any detail. Rather, I wish only to suggest how ignoring, or exploring, the social movement roots of the

${ }_{83}^{82} 261$ U.S. 525 (1923).

${ }^{83}$ Id. at 553; see also Siegel, supra note 64 (manuscript at 56) ("The Court took [the Nineteenth Amendment] into account as it reasoned about the gendered structure of substantive due process doctrine in the aftermath of the amendment's ratification.").

${ }^{84}$ Siegel, supra note 64 (manuscript at 56). For another approach to synthetic interpretation of the Fourteenth and Nineteenth Amendments, see Michael C. Dorf, A Textual Basis for an Anti-Discrimination Principle (2001) (unpublished manuscript, on file with author) (arguing for an "incorporationist" account of the Equal Protection Clause that reads the Fourteenth Amendment in light of the nondiscrimination provisions contained in the First, Fifteenth, Nineteenth, and Twenty-Sixth Amendments). Vicki Jackson has recently advanced the case for reading the Constitution holistically in light of its recent amendment. She argues:

The Fifteenth (1870), Nineteenth (1920), Twenty-Fourth (1964), and Twenty-

Sixth (1971) Amendments all sought to expand and secure the right to vote.

They thus can be read as elaborations of the basic message of equality of national citizenship founded in Section 1 of the Fourteenth Amendment. Their frequency and relative currency vis-à-vis 1789 makes plausible the argument that these amendments should be understood as importantly redefining what the basic values of this Constitution are and to some extent revising our understanding of what the powers of the national government are.

Vicki C. Jackson, Holistic Interpretation: Fitzpatrick v. Bitzer and Our Bifurcated Constitution, 53 STAN. L. REV. 1259, 1290-91 (2001) (footnotes omitted). 
Nineteenth Amendment might bear on the ways we understand its meaning today. What understanding of Article $V$ lawmaking produces the "thin" Nineteenth Amendment that Strauss and most other constitutional lawyers presently dismiss as "irrelevant"? What shift in perspective might produce a "thicker" understanding of the Nineteenth Amendment as the site of normative struggle of continuing relevance to the ways we interpret the Constitution today? More specifically, how might examining the dynamics of mobilization and countermobilization around the Woman Question alter our judgments about the Nineteenth Amendment's normative ambit or subject matter concerns?

When Strauss reasons about the importance of enfranchising women under the Constitution, he presumes that a consensus to enfranchise women has formed in "political culture" that can be enforced through an act of lawmaking, whether under federal or state law. ${ }^{85}$ Here, as elsewhere, Strauss reasons from a classically instrumentalist view of constitutional lawmaking; he assumes that the purpose of law is to enforce society's norms by regulating the conduct of those who would resist them. ${ }^{86}$ But we need not assess the dynamics of constitutional change only at the point that the Constitution becomes an instrument for compelling resisting states to grant women the right to vote. Instead we could explore the role the Constitution played in forming the "political culture" favoring the enfranchisement of women that Strauss's analysis assumes. Such an inquiry would start well before large numbers of Americans thought it unjust to deny women the vote and would examine the role that debate over the Constitution played in forming this understanding.

In what follows, I identify some ways in which debates over the Constitution helped transform the United States from a society in which male suffrage was an unquestioned norm to a society in which restrictions on women voting were understood to violate democratic values. This brief sketch of suffrage history illustrates how core understandings and practices of our constitutional culture helped create the political consensus that was ultimately memorialized in the Constitution through an act of Article $\mathrm{V}$ lawmaking. This alternative account of constitution making, I suggest, has implications for the ways we rea-

${ }^{85}$ See Strauss, Irrelevance, supra note 1, at 1503 ("[W] hat controls the pace of change is the culture, not the amendment.").

${ }^{86}$ See supra notes 50-51 and accompanying text (discussing the instrumentalist view of constitutional law on which Strauss's argument rests). 
son about the Constitution's meaning.

Debates over the Constitution helped create and give defining organizational shape to the nineteenth-century woman's suffrage movement. ${ }^{87}$ It was the Republican Party's decision to exclude woman suffrage from the Reconstruction amendments that riveted the attention of the nineteenth-century woman's rights movement on the goal of enfranchising women under the Constitution. After failing in its effort to intervene in the drafting of the Civil War Amendments, the movement split into two organizations that differed about whether to support former abolitionist allies in the Republican Party by pursuing suffrage as a state law reform or to challenge the Republican Party over the terms of the post-war constitutional order. ${ }^{88}$

Under the leadership of Susan B. Anthony and Elizabeth Cady Stanton, the National Woman's Suffrage Association (NWSA) began to claim the right to vote through interpretive and amendatory claims on the Federal Constitution, which the movement advanced in a variety of venues. While Stanton and Anthony initially responded to ratification of the Fourteenth and Fifteenth Amendments by seeking a new constitutional amendment that would protect women's right to vote, they soon abandoned this effort to lead a grassroots campaign that was premised on the view that women were already entitled to vote under the Privileges and Immunities Clause of the newly ratified Fourteenth Amendment. ${ }^{\text {*9 }}$

As part of this "New Departure" strategy for interpreting the postwar Constitution, movement leaders petitioned Congress for a Section Five statute declaring that the Fourteenth Amendment protected

${ }^{87}$ In the antebellum period, the woman's rights movement used the Declaration of Independence as a template for its inaugural Declaration of Sentiments. Infra note 98 and accompanying text. In this period, however, suffrage was but one of the movement's claims, of no greater significance than efforts to reform the law of marriage, and possibly of lesser significance. See STEVEN M. BUECHLER, THE TRANS. FORMATION OF THE WOMAN SUFFRAGE MOVEMENT: THE CASE OF ILlinOIS, 1850-1920, at 38-41 (1986) (describing shifts in the breadth of the movement's demands over the course of the nineteenth century). Unquestionably all of the movement's reform en-

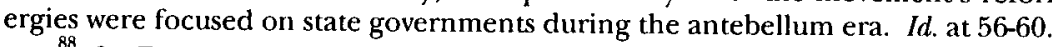

${ }^{88}$ See Ellen Carol dubois, Feminism and Suffrage: The Emergence of aN INDEPENDENT WOMEN'S MOVEMENT IN AMERICA, 1848-1869 (1978) (demonstrating how the first organization of the suffrage movement arose out of post-war conflicts over the Constitution).

${ }^{89}$ For a full account of the movement's constitutional claims, in the era of the New Departure and after, see Siegel, supra note 64 (manuscript at 20-26). 
women's right to vote,,$^{90}$ while women across the nation engaged in civil-disobedience voting designed to produce test-case constitutional litigation. In so doing, the post-war movement self-consciously built upon abolitionist constitutional theory, ${ }^{91}$ but it publicized its interpretive claims using startlingly modern techniques to contest and transform constitutional meaning-in the courts as well as the court of public opinion. ${ }^{92}$ It was only in 1875 , when the Supreme Court definitively ruled in Minor $v$. Happersett, ${ }^{93}$ that the Fourteenth Amendment did not protect women's right to vote that NWSA concertedly began to pursue a constitutional amendment. Congress initially appeared receptive to the Amendment, ${ }^{94}$ but the movement did not secure its ratification for another three decades.

In the decades of struggle over the question of women voting that ensued, NWSA and the American Woman Suffrage Association (AWSA) petitioned, lobbied, and demonstrated in an effort to secure the right to vote under federal and state law. To achieve these objectives, suffragists had to present their case in terms calculated to persuade a male electorate to support their cause; yet they also had to argue their case in terms that would persuade a historically disfranchised female electorate to join their ranks. In the process, the movement's efforts to secure constitutional change changed the meaning of women voting. As one considers the dynamics of mobilization and countermobilization, one can better appreciate how the quest for constitutional reform imbued woman suffrage with powerful symbolic and associative significance.

In addressing the male audience whom they were attempting to persuade to enfranchise women, suffragists made claims about inter-

90 Id. at 23.

${ }^{91}$ Lobel, supra note 14, at 1356; Siegel, supra note 64 (manuscript at 23 \& n.64); Adam Winkler, A Revolution Too Soon: Woman Suffragists and the "Living Constitution," 1869-1875, 76 N.Y.U. L. REV. 1456, 1468-69 (2001).

${ }^{92}$ For some accounts of the New Departure, see Ellen Carol DuBois, Outgrowing the Compact of the Fathers: Equal Rights, Woman Suffrage, and the United States Constitution, 18201878, in WOMAN SUFFRAGE AND WOMEN's RIGHTS 81, 98-106 (1998); Lobel, supra note 14, at 1364-75; Siegel, supra note 64 (manuscript at 22-23); Winkler, supra note 91, at 1458-59.

${ }^{93} 88$ U.S. $162(1875)$.

${ }^{94}$ In 1882 , both houses of Congress appointed select committees on woman's suffrage, each of which recommended passage of an amendment; in 1887, the Amendment was brought to a vote on the Senate floor, where it was defeated. ALEXANDER Keyssar, THE Right to Vote: THE CONTESTEd History OF DEMOCRACY IN THE. UNITED STATES $185(2000)$. 
preting or amending the Constitution that drew on core values, understandings, and memories of American political life. This was so during the period of the New Departure, when the movement was arguing for enfranchisement by interpretation, and after, when the movement was arguing for enfranchisement by amendment. ${ }^{95}$ The movement depicted self-representation as a foundational right in the American constitutional tradition, ${ }^{96}$ and contested the claim that women were represented in the state through male heads of households by demonstrating all the ways that the law failed fully or fairly to represent women's interests. ${ }^{97}$

95 The movement often argued that women's right to vote was already protected by the Constitution in the course of advocating that the Constitution be amended to recognize women's right to vote:

By every principle of fair interpretation we need no new amendment, no new definitions of the terms "people," "persons," "citizens," no additional power conferred on Congress to enable this body to establish a republican form of government in every State of the Union; and whenever our rulers are ready to make the experiment they will see that they already possess all the constitutional power they need to act, and that the right of suffrage is, and always was, the inalienable right of every citizen under government.

Hearing Before the S. Comm. on Woman Suffrage, S. MISC. DoC. No. 50-114, at 3 (1888) (statement of Elizabeth Cady Stanton). Susan B. Anthony stated that:

The Constitution of the United States as it is protects me. If I could get a practical application of the Constitution it would protect me and all women in the enjoyment of perfect equality of rights everywhere under the shadow of the American flag.

I do not come to you to petition for special legislation, or for any more amendments to the Constitution, because I think they are unnecessary, but because you say there is not in the Constitution enough to protect me. Therefore I ask that you, true to your own theory and assertions, should go forward to make more constitution.

Arguments of the Woman-Suffrage Delegates: Hearing Before the S. Comm. on the Judiciary, S. MISC. DOC. No. 97-74, at 12 (1880) [hereinafter 1880 Senate Hearing] (statement of Susan B. Anthony).

${ }^{10}$ See, e.g., Hearing Before the S. Comm. on Woman Suffrage, S. Misc. Doc. NO. 53-121, at 25 (1894) (remarks of Sara Winthrop Smith) ("The right of women to vote began with the first pronunciamento against the tyranny of England. It is as firmly placed in the fundamental laws of our country as is the same right of men."). The call to NWSA's eighth annual convention declared that "the Declaration of Independence was the first national assertion of the right of individual representation. That 'governments derive their just powers from the consent of the governed,' thenceforward became the watchword of the world. Our flag, which beckons the emigrant from every foreign shore, means to him self-government." Call for the Eighth Annual Washington Convention (1876), reprinted in 3 HISTORY OF WOMAN SUFFRAGE 3 (Elizabeth Cady Stanton et al. eds., 1886) [hereinafter 3 HWS].

${ }^{97}$ See generally Siegel, supra note 64 (manuscript at 40-41) (noting as examples unfair employment compensation and marital property rules, and a lack of protection against physical coercion in marriage). 
As they constructed constitutional arguments to contest the justice of women's disfranchisement, suffragists repeatedly invoked the memory of the American Revolution. In 1848, the woman's rights movement had drafted its inaugural Declaration of Sentiments in the language of the Declaration of Independence, ${ }^{98}$ and from this first enumeration of grievances onward, challenged women's disfranchisement by invoking the nation's revolutionary heritage. Memories of the Revolution may well have provided the only narrative resources that were powerful enough to contest the discourse of familialism through which women's disfranchisement was justified. ${ }^{99}$ Suffragists tacitly invoked the relations of colonists and king in their frequent invocation of the creed "no taxation without representation," and in their repeated efforts to demonstrate how a regime of virtual representation provided women no effective representation at all. ${ }^{100}$ During the $1870 \mathrm{~s}$ - the decade of the Centennial-suffragists augmented the civil disobedience voting protests of the New Departure with a wave of tax protests that framed their quest for the vote in the traditions of colonial revolutionary protest. ${ }^{101}$

${ }^{98}$ See Declaration of Sentiments (1848) (describing the "history of mankind [as] a history of repeated injuries and usurpations on the part of man toward woman, having in direct object the establishment of an absolute tyranny over her"), reprinted in 1 HISTORY OF WOMAN SUFFRAGE 70, 70 (Elizabeth Cady Stanton et al. eds., 1881).

"Compare the testimony of Elizabeth Saxon:

I beg of you, gentlemen, to consider this question [the Sixteenth Amendment] apart from the manner in which it was formerly considered. We, as the women of the nation, as the mothers, as the wives, have a right to be heard, it seems to me, before the nation. We represent precisely the position of the colonies when they plead, and, in the words of Patrick Henry, they were "spurned with contempt from the foot of the throne." We have been jeered and laughed at, and ridiculed; but this question has passed out of the region of ridicule.

1880 Senate Hearing, supra note 95, at 6 (statement of Elizabeth L. Saxon).

${ }^{100}$ For example, Mary Stewart testified that:

We are taxed without representation; there is no mistake about that. The colonies screamed that to England; Parliament screamed back, "Be still; long live the King, and we will help you." Did the colonies submit? They did not. Will the women of this country submit? They will not. Mark me, we are the sisters of those fighting revolutionary men; we are the daughters of the fathers who sang back to England that they would not submit. Then if the same blood courses in our veins that courses in yours, dare you expect us to submit? 1880 Senate Hearing, supra note 95, at 6-7 (statement of Mary A. Stewart); see also Siegel, supra note 64 (manuscript at 39) (observing how suffrage arguments based on the Declaration of Independence and the Titles of Nobility and Bills of Attainder Clauses evoked memories of the Revolution).

${ }^{101}$ On the tax protests, see LINDA K. KeRBER, No ConSTITUTIONAL RiGitT TO BE 
By invoking the nation's revolutionary heritage to contest the justice of women's representation through the family, the movement constructed a powerful challenge to male suffrage; no other political narrative offered such a potent rejoinder to men's claim to represent women in the state. And yet, precisely as suffragists invoked core understandings of the American political tradition to justify the claim that women's right to vote should be protected by the Constitution, suffragists were advancing a politically explosive reinterpretation of gender relations in the family and in the state. ${ }^{102}$ Male superordination was not benign, but tyrannical, ${ }^{103}$ and fundamentally unjust. ${ }^{104}$

LADIES: WOMEN AND THE Obligations OF CITIZENSHIP 81-123 (1998). See also KEYSSAR, supra note 94, at 182 ("In scattered locales throughout the country, women refused to pay their taxes as long as they were prevented from voting, insisting that it was unconstitutional to impose the obligations of citizenship on them while they were deprived of political rights."). On the woman suffrage protests held during the Centennial, see 3 HWS, supra note 96, at 27-31. Belva Lockwood, the first woman to run for President, gave a speech at an 1878 NWSA convention that pressed the movement's revolutionary themes to unusually explicit extremes. Lockwood argued:

The only way for women to get their rights is to take them. If necessary let there be a domestic insurrection. Let young women refuse to marry, and married women refuse to sew on buttons, cook, and rock the cradle until their liege-lords acknowledge the rights they are entitled to. There were more ways than one to conquer a man; and women, like the strikers in the railroad riots, should carry their demands all along the line.

Belva A. Lockwood, Remarks at the Tenth Washington Convention (Jan. 9, 1878), reprinted in id. at 73.

${ }^{102}$ Elizabeth Cady Stanton pursued this strategy quite self-consciously:

But what do lofty utterances and logical arguments avail so long as men, blinded by old prejudices and customs, fail to see their application to the women by their side? Alas! gentlemen, women are your subjects. Your own selfish interests are too closely interwoven for you to feel their degradation, and they are to dependent to reveal themselves to you in their nobler aspirations, their native dignity.

Argument of Isabelle Beecher Hooker Before the S. Comm. on the Judiciary, 42d Cong. (1872) (statement of Elizabeth Cady Stanton), reprinted in 2 HISTORY OF WOMAN SUFFRAGE 510 (Elizabeth Cady Stanton et al, eds., 1882).

${ }^{103}$ See Declaration of Sentiments, supra note 98 , at 70 (drawing on the Declaration of Independence to describe the "history of mankind [as] a history of repeated injuries and usurpations on the part of man toward woman, having in direct object the establishment of an absolute tyranny over her").

${ }^{104}$ The movement emphasized this theme during the Centennial celebrations on July 4, 1876, when Susan B. Anthony stood in front of Independence Hall and read from NWSA's Declaration of Rights for Women:

Universal manhood suffrage, by establishing an aristocracy of sex, imposes upon the women of this nation a more absolute and cruel despotism than monarchy; in that, woman finds a political master in her father, husband, brother, son. The aristocracies of the old world are based upon birth, wealth, refine- 
The threat was not limited to the claims about male power that arguments from the Revolution implicitly, or explicitly, advanced. Suffragists demonstrated their claims about the injustice of men representing women by pointing to the many ways that laws made by men served male interests. ${ }^{105}$ This critique of virtual representation was not merely aimed at the male audience that the movement was endeavoring to persuade; it was also aimed at the disfranchised women whom the movement was endeavoring to attract to the suffrage cause.

For, during the many decades that the suffrage movement pursued constitutional reform, it was not merely attempting to persuade those with power to share it; it was also attempting to persuade those without power to join its ranks. Throughout this period, suffragists attempted to recruit new members to their cause by demonstratingthrough movement newspapers, conventions, and protests-how disfranchisement harmed women. As the movement endeavored to persuade women why they needed the right to vote and so should join its ranks, the movement tied the right to vote to all manner of social concerns ranging from pay equity and job access to family law concerns, including marital rape and expropriation of the value of women's household labor. ${ }^{106}$ As the movement widened its class base, it also began to represent the enfranchisement of women as a means to "social housekeeping": a world in which women would have a say in the regulation of municipal services and the industrial conditions in which they and their children worked. ${ }^{107}$

ment, education, nobility, brave deeds of chivalry; in this nation, on sex alone; exalting brute force above moral power, vice above virtue, ignorance above education, and the son above the mother who bore him.

Declaration of Rights for Women (1876), reprinted in 3 HWS, supra note 96, at 33; see also A Sixteenth Amendment to the Constitution of the United States Prohibiting the Several States from Disfranchising United States Citizens on Account of Sex: Hearings Before the S. Comm. on Privileges and Elections, 45th Cong. 5 (1878) (testimony of Elizabeth Cady Stanton) ("When we place in the hands of one class of citizens the right to make, interpret, and execute the law for another class wholly unrepresented in the government, we have made an order of nobility. Universal manhood suffrage makes all men sovereigns, all women slaves-the most odious form of aristocracy the world has yet seen.").

${ }^{105}$ Cf. supra note 102 (quoting Elizabeth Cady Stanton making this claim).

${ }^{106}$ Siegel, supra note 64 (manuscript at 40-41).

107 See AlleEN S. KRADITOR, THE IDEAS OF THE WOMAN SuFfraGe Movement, 1890-1920, at 66-71 (W.W. Norton \& Co. 1981) (1965) (discussing the argument that women needed the vote in order to secure the health and welfare of their families); see also Jane Addams, Why Women Should Vote, in ONE WOMAN, ONE VOTE: REDISCOVERING THE WOMAN SUFFRAGE MOVEMENT 195 (Marjorie Spruill Wheeler ed., 1995) (providing the classic expression of this argument). On the expansion of the class base of the 
For some time now, historians of the woman suffrage movement have characterized this shift in movement rhetoric as a shift from "justice"-based to "expedience"-based arguments for the vote. ${ }^{108}$ But this way of characterizing the movement's efforts to recruit women to the suffrage cause seems to castigate suffragists for engaging in forms of advocacy that are a normal phase of mobilization, which social movement theorists refer to as frame alignment: a movement's attempt to represent or reinterpret daily life in terms calculated to move individuals to action. ${ }^{109}$ If one analyzes mobilization for constitutional change from the standpoint of the frame alignment literature, it becomes much easier to understand how the woman suffrage question came to be systematically associated with a range of challenges to male prerogatives and power, by proponents and opponents alike.

During the half-century spanning the Reconstruction and Progressive Eras, as the movement advanced its interpretive and amendatory claims on the Constitution, social movement activity insistently associated the question of women voting with core understandings of the American constitutional tradition and, at the same time, associated women's suffrage with challenges to a variety of gendered institutions and practices, the male-headed household first among them. Thus, as the polity struggled over the question of whether the American democratic tradition required the enfranchisement of women, it was simultaneously wrestling with the challenges to male privilege that the woman suffrage movement voiced as it recruited women to the suffrage cause and attempted to refute the claim that women were represented in the state through the men of their households.

In this period, prior to ratification, even though there had yet

suffrage movement in the first decades of the twentieth century, see ELLEN CAROL DuBois, HaRriot Stanton Blatch AND the WinNing OF WOMAN SUFFrage 94-106 (1997).

${ }^{108}$ KRADITOR, supra note 107 , at 52-74.

109 See David A. Snow et al., Frame Alignment Processes, Micromobilization, and Movement Participation, 51 AM. SOC. REV, 464, 464 (1986) (defining "frame alignment" as "the linkage of individual and SMO [social movement organization] interpretive orientations, such that some set of individual interests, values, and beliefs and SMO activities, goals, and ideology are congruent and complementary"). For an overview of recent scholarship that explores how social movements produce meaning as a predicate to collective action, see FrontIERS IN SOCIAL MOVEMENT THEORY (Aldon D. Morris \& Carol McClurg Mueller eds., 1992). For an analysis of the women's movement that draws on several branches of this scholarship, see Verta Taylor \& Nancy Whittier, Analytical Approaches to Social Movement Culture: The Culture of the Women's Movement, in SOCIAL MOVEmenTS AND CulTuRE 163 (Hank Johnston \& Bert Klandermans eds., 1995). 
been no act of constitutional lawmaking, the Constitution was nonetheless shaping social life: debates about the Constitution's meaning channeled conflict about a variety of gendered institutions, practices, and understandings into the question of women's right to vote. ${ }^{110}$ The arguments of suffragists and their opponents tied the idea of women voting to the prospect of women's emancipation from traditional roles in marriage and the market. Once the question of woman suffrage was infused with this social meaning-once the question of woman suffrage was known simply as the "woman question"- the nation's debate about whether women should vote turned into a referendum on a whole range of gendered institutions and practices. It was because the question of women voting was so symbolically charged that the debate over the Constitution lasted as long as it did.

Analyzed from this standpoint, the woman suffrage movement was less successful than Strauss depicts. The woman suffrage movement obtained the right to vote, and with recognition of this right moved closer to the social world it aspired to realize through enfranchisement, but by no means did ratification of the Nineteenth Amendment bring about the social transformations that its proponents sought and its opponents feared. The movement's mixed record of accomplishment can be traced to many causes, among them internal divisions in the ranks of the broad-based social movement that coalesced around the goal of enfranchisement and diverse forms of backlash that the movement's very success in securing change precipitated. ${ }^{\prime \prime \prime}$

Indeed we can see anxieties about the changes precipitated by enfranchisement as playing a role in the interpretation of the Nineteenth Amendment itself. The Supreme Court initially interpreted the Nineteenth Amendment in light of the social meanings of the suffrage campaign. Adkins treated ratification of the Nineteenth Amendment as marking an epochal transformation in gender relations that had structural significance for the interpretation of other bodies of constitutional law; ${ }^{112}$ yet, neither the Supreme Court nor many state courts maintained this approach for long thereafter. ${ }^{113}$ In-

${ }^{110}$ See, e.g., supra text accompanying note 106 ("[T] he movement tied the right to vote to all manner of social concerns ranging from pay equity and job access to family law concerns ....").

${ }^{111}$ See Siegel, supra note 64 (manuscript at $55 \mathrm{n} .185$ ) (citing sources that examine post-ratification responses to the Nineteenth Amendment).

${ }^{112} I d$. at 56 (analyzing Adkins v. Children's Hospital, 261 U.S. 525 (1923)).

${ }^{113}$ See id. at 60-61 (noting that, in the aftermath of the Nineteenth Amendment's ratification, some federal and state courts "interpreted the suffrage amendment as dis- 
stead, courts began to interpret the Amendment in ways that stripped the question of women voting of the social meaning it acquired during the long course of the suffrage campaign. Through such practices of interpretation, federal and state courts domesticated the suffrage amendment and helped transform it into a rule devoid of larger constitutional significance.

To this point I have been exploring aspects of the Nineteenth Amendment's history that are visible if one puts aside paradigms concerned with lawmaking and instead examines the role that our constitutional culture played in supporting social movement organization around the question of enfranchising women. We may then wish to ask: how might considering the Nineteenth Amendment from a social movement perspective bear on the ways we interpret it today? A full answer to this question plainly exceeds the bounds of this Article. For present purposes, I wish to observe only the following.

Just as we can reason about the significance of Article $\mathrm{V}$ in a framework that focuses on acts of constitutional lawmaking or the understandings and practices of constitutional culture, we can reason about the meaning of Article $\mathrm{V}$ amendments in these different analytical frameworks, as well. Do the constitution-making efforts of past generations of Americans matter to us only as they impose constraints on us? If this is our relation to preceding generations-if our sole interest in their undertakings is to ascertain the forms of compulsion to which they have subjected us-then our interest in their constitutional undertakings is accordingly restricted to determining the content and scope of the injunctions they have promulgated for us. If, however, we stand in a different relation to prior generations, if their struggles are of significance to our own constitutional undertakings not merely as law that constrains us but as history that might inform and shape the ways that we understand and justify our own acts of constitution making, then we will want to know very different things about constitutional deliberations of the past.

The question thus turns on the ways we understand the role of history in constitutional argument. Most commonly, constitutional theory depicts constitutional history within a lawmaking framework, as important insofar as it reveals the nature and scope of constraints that bind us. ${ }^{114}$ But if we examine ordinary practices of constitutional ar-

establishing the marital status traditions of the common law" but that "this understanding of constitutional reform never gathered significant momentum").

${ }^{114}$ Constitutional theory invokes history as a ground for constitutional law in a 
gument and justification, it is plain that in our constitutional culture we also turn to history as a source of narrative understanding. It is history that supplies the narrative materials through which we forge the collective subject-"We the People"-that is realized through the practice of constitutional argument; and it is history that supplies the field of collective experience through which we make pragmatic judgments about how to realize constitutional commitments and values in practice. This kind of appeal to history, as a source of narrative understanding, of collective identity, and of practical judgment about constitutional values, is a fundamental feature of our constitutional culture, regularly invoked in constitutional argument inside and outside the courts.

Considered from the standpoint of constitutional culture, then, history matters, but not for the reasons constitutional theory most commonly identifies: as a source of law or compulsion. However much we venerate the Founders, we do not live under the Constitution as a regime of paternal authority, as the law of the father. Rather, we live under the Constitution as "our" Constitution, as a framework in which we make decisions through which we are constituted and for which we are responsible, as a people. On the latter account, the past exerts force, not as it binds our choices but as it informs our choicesas it guides them and gives them meaning. We look to the past as we make pragmatic judgments about how to vindicate constitutional values in the present. And we look to the past as we struggle to define ourselves as a nation acting in history, united imaginatively and ethically across generations as well as communities. ${ }^{115}$

As one reflects on the practices of appealing to the past that play such a central role in constitutional argument both inside and outside

wide variety of paradigms. Theories of originalism and textualism treat the history of the Constitution's making as a constraining source of law, while other practices and schools of interpretation approach the Constitution in a manner akin to an informing tradition, and accordingly approach the past for an understanding of the nation's identity, customs, and accumulated wisdom in practical matters concerning the vindication of constitutional values.

${ }^{115}$ Identitarian and ethical modes of reasoning each have temporal, crossgenerational extension. Jed Rubenfeld argues that concepts of self-government, properly understood, incorporate temporal extension as well. On his account, written constitutionalism is properly understood as a nation's struggle to lay down and live out its own fundamental political commitments over time. See JED RuBENFELD, FREEDOM AND Time: A ThloRY of Constitutional SElF-GOVERNMENT 11 (2001) (arguing that "democratic self-government is itself something that exists, if it exists at all, only over time"). 
of the courts, it is apparent that history matters in constitutional argument because the Constitution's authority resides in forms of understanding, and not merely threats of compulsion. With this more expansive understanding of the role of history in constitutional argument, we have reason to take account of constitutional mobilizations that satisfy Article $\mathrm{V}$ criteria of lawmaking and those that do not, of constitutional interpreters that hold elected or appointed office and those that do not, and of constitutional claims that secure formal recognition and those that do not. Our interest in the life of the Constitution in times past extends beyond the understandings of those we designate "framers" and the acts we characterize as lawmaking to the nation's experience living under the Constitution as both the nation and its Constitution evolve in history. And if we act with this understanding of the role of history in constitutional reason, it is plain that the "thick" account of the Nineteenth Amendment's roots in social movement struggle bears-in myriad ways-on how we interpret the Constitution today."

To cite one locally germane example: the history of the Nineteenth Amendment teaches that in our constitutional culture, no institutional authority, not even the Court, has the power to fix the Constitution's meaning in a way that can insulate it from challenge. Indeed, the history of social movement challenges to prevailing constitutional orthodoxies shows that in our constitutional culture, mobilized citizenry have played a central role in forging constitutional understandings that we now venerate as core features of our constitutional order. Mobilized groups of citizens realized these alternative understandings and aspirational visions of the American constitutional order through a variety of transformative practicessometimes with the help of a responsive judiciary, and, as the Nineteenth Amendment reminds us, sometimes by overcoming deeply entrenched resistance in the representative branches of government as well as the courts.

${ }^{116}$ For a full elaboration of this argument, see Siegel, supra note 64, which demonstrates how the history of the suffrage struggle bears in different ways on the various branches of constitutional doctrine that the Supreme Court invoked in justification of its decision in United States v. Morrison, 529 U.S. 598 (2000), to strike down provisions of the Violence Against Women Act. 


\section{CONCLUSION}

Over the life of the Republic, social movements have played a significant role in shaping constitutional understandings, but constitutional theory barely recognizes the role that constitutional mobilizations play in the construction of constitutional meaning. In this Article, I trace the marginalization of social movements in constitutional theory to a tendency among constitutional theorists to model relations that bear on constitutional interpretation in paradigms of lawmaking-a set of restrictive criteria for determining when constitutions change and how.

Relations between citizenry and judiciary, as well as between past and present generations of Americans, continuously shape the production of constitutional meaning, but through more complex pathways than lawmaking paradigms recognize. When David Strauss disparages the significance of text and amendment in our constitutional tradition, ${ }^{117}$ he is in fact reasoning about text and amendment within conventional accounts of constitutional lawmaking. But if we analyze the question from the standpoint of constitutional culture, we can see that text and amendment play a more significant role in our tradition than Strauss's account of common law constitutionalism and other court-focused constitutional theories recognize. Text matters in our tradition because it is the site of understandings and practices that authorize, encourage, and empower ordinary citizens to make claims about the Constitution's meaning.

In our constitutional culture, elected officials and ordinary citizens understand themselves as authorized to make claims about the Constitution's meaning and regularly act on this understanding in a wide variety of social settings and through an array of practices, only some of which are formally identified in the text of the Constitution itself. Considered from this positive standpoint, courts are not the Constitution's sole expositors; instead, as judges interpret the Constitution they are regularly informed by, and intervene in, controversies about the Constitution that are proceeding outside of the courts.

Political scientists, sociologists, and historians can describe these relationships, to be sure, but constitutional theory needs to generate richer positive descriptions of them as well. The Rehnquist Court is presently refashioning numerous bodies of doctrine that regulate re-

\footnotetext{
${ }^{117}$ Supra text accompanying notes $4,6-7$.
} 
lations between Congress and the Court. ${ }^{118}$ These doctrines were premised on an understanding, forged in the mid-twentieth century, that Congress and the Court each had responsibilities for constitutional interpretation, within its proper sphere. ${ }^{119}$ As the Rehnquist Court abandons practices of deference to congressional lawmaking that have been entrenched in constitutional doctrine since the midtwentieth century in favor of practices of aggressive judicial review, it stakes its constitutional prerogative to strike down federal laws on the view that judicial interpretation of the Constitution restricts other branches from reasoning about its meaning.

The Court first began to emphasize this view in City of Boerne v. Flo$r e s,{ }^{120}$ in the course of striking down the Religious Freedom Restoration Act (RFRA). In Boerne, the Court was plainly provoked by what it viewed as a congressional challenge to its authority to interpret the Constitution. ${ }^{121}$ Whether or not Congress's use of its powers under Section Five of the Fourteenth Amendment to enact the RFRA represented such a challenge, the case certainly involved the two branches of the federal government in a dispute about the framework that would best vindicate free exercise values; Congress publicly announced that it was enacting the RFRA to provide legislative protection for free exercise rights in a framework that the Supreme Court

${ }^{118}$ The Court is striking down provisions of various civil rights statutes on the grounds that Congress lacked the power to enact them. See, e.g., Bd. of Trs. of Univ. of Ala. v. Garrett, 121 S. Ct. 955 (2001) (Americans with Disabilities Act); Morrison, 529 U.S. at 598 (Violence Against Women Act); Kimel v. Fla. Bd. of Regents, 528 U.S. 62 (2000) (Age Discrimination in Employment Act).

${ }^{119}$ See, e.g., City of Boerne v. Flores, 521 U.S. 507, 535 (1997) ("When Congress acts within its sphere of power and responsibilities, it has not just the right but the duty to make its own informed judgment on the meaning and force of the Constitution. This has been clear from the early days of the Republic.").

\footnotetext{
${ }^{120}$ Id.

${ }^{121}$ The Court stated:
}

Our national experience teaches that the Constitution is preserved best when each part of the Government respects both the Constitution and the proper actions and determinations of the other branches. When the Court has interpreted the Constitution, it has acted within the province of the Judicial Branch, which embraces the duty to say what the law is. Marbury $v$. Madison, [5 U.S. (1 Cranch) 137, 177 (1803)]. When the political branches of the Government act against the background of a judicial interpretation of the Constitution already issued, it must be understood that in later cases and controversies the Court will treat its precedents with the respect due them under settled principles, including stare decisis, and contrary expectations must be disappointed.

521 U.S. at 535-36. 
had rejected in one of its recent decisions interpreting the Free Exercise Clause. ${ }^{122}$

But in subsequent cases, the Court has invoked Boerne as precedent for striking down federal laws that Congress enacted with no thought of creating legislative alternatives to the Court's interpretation of the Constitution: for example, the provisions of the Age Discrimination in Employment Act in Kimel, ${ }^{123}$ provisions of the Violence Against Women Act in Morrison, ${ }^{124}$ and provisions of the Americans with Disabilities Act in Garrett. ${ }^{125}$ In adopting these laws, Congress understood itself to be exercising its powers under the Commerce Clause and Fourteenth Amendment to enact civil rights legislation, just as it had done regularly during the second half of the twentieth century. The separation-of-powers problem in these cases appeared, not because Congress differed with the Court about the Constitution's meaning, but because the Court adopted a new, and less deferential, doctrinal framework for reviewing exercises of congressional lawmaking.

The new doctrinal framework that the Court adopted for evaluating exercises of congressional power under Section Five-Boerne's "congruence and proportionality" test-emphasizes that the Court must closely scrutinize exercises of congressional lawmaking to ensure that Congress does not encroach on the Court's prerogative to interpret the Constitution. ${ }^{126}$ In adopting the Boerne test, the Court gives Congress manifestly less deference in exercising an enumerated

${ }^{122}$ For discussion of the struggle between the Court and Congress, see Post \&c Siegel, supra note 13 , at 453 .

528 U.S. at 91.

${ }^{124}$ United States v. Morrison, 529 U.S. 598, 627 (2000).

${ }^{125}$ Bd. of Trs. of Univ. of Ala. v. Garrett, 121 S. Ct. 955, 963-68 (2001).

${ }^{126}$ As the Court explained in Boerne.

Congress does not enforce a constitutional right by changing what the right is. It has been given the power "to enforce," not the power to determine what constitutes a constitutional violation. Were it not so, what Congress would be enforcing would no longer be, in any meaningful sense, the "provisions of [the Fourteenth Amendment]."

While the line between measures that remedy or prevent unconstitutional actions and measures that make a substantive change in the governing law is not easy to discern, and Congress must have wide latitude in determining where it lies, the distinction exists and must be observed. There must be a congruence and proportionality between the injury to be prevented or remedied and the means adopted to that end. Lacking such a connection, legislation may become substantive in operation and effect.

521 U.S. at 519-20 (alteration in original). 
power than is ordinarily the case in our constitutional order, ${ }^{127}$ and it does so on the stated ground that congressional lawmaking involving constitutional interpretation that varies from the Court's threatens the integrity of our constitutional order. Completely obscured is the possibility that, by reason of institutional differences between Congress and the Court, legislative and judicial interpretation of the Fourteenth Amendment might legitimately differ. ${ }^{128}$

${ }^{127}$ See, e.g., Garrett, 121 S. Ct. at 975 (Breyer, J., dissenting) ("The courts' harsh review of Congress' use of its $\$ 5$ power is reminiscent of the similar (now-discredited) limitation that it once imposed upon Congress' Commerce Clause power."); 1 LAURENCE H. TRIBE, AmErican Constitutional LAW $\$ 5-16$, at 959 (3d ed. 2000) (“[L]aws enacted by Congress pursuant to $\$ 5$ suddenly [have] been saddled with something between intermediate and strict scrutiny ....").

${ }^{128}$ This theme is the focus of Justice Breyer's dissent in Garrett:

The problem with the Court's approach is that neither the "burden of proof" that favors States nor any other rule of restraint applicable to judges applies to Congress when it exercises its $\$ 5$ power. "Limitations stemming from the nature of the judicial process ... have no application to Congress." Rational-basis review-with its presumptions favoring constitutionality-is "a paradigm of judicial restraint." And the Congress of the United States is not a lower court.

$\cdots$

There is simply no reason to require Congress, seeking to determine facts relevant to the exercise of its $\$ 5$ authority, to adopt rules or presumptions that reflect a court's institutional limitations. Unlike courts, Congress can readily gather facts from across the Nation, assess the magnitude of a problem, and more easily find an appropriate remedy. Unlike courts, Congress directly reflects public attitudes and beliefs, enabling Congress better to understand where, and to what extent, refusals to accommodate a disability amount to behavior that is callous or unreasonable to the point of lacking constitutional justification. Unlike judges, Members of Congress can directly obtain information from constituents who have first-hand experience with discrimination and related issues.

Moreover, unlike judges, Members of Congress are elected. When the Court has applied the majority's burden of proof rule, it has explained that we, i.e., the courts, do'not "sit as a superlegislature to judge the wisdom or desirability of legislative policy determinations." To apply a rule designed to restrict courts as if it restricted Congress' legislative power is to stand the underlying principle - a principle of judicial restraint-on its head. But without the use of this burden of proof rule or some other unusually stringent standard of review, it is difficult to see how the Court can find the legislative record here inadequate. Read with a reasonably favorable eye, the record indicates that state governments subjected those with disabilities to seriously adverse, disparate treatment. And Congress could have found, in a significant number of instances, that this treatment violated the substantive principles of justification-shorn of their judicial-restraint-related presumptions-that this Court recognized in Cleburne.

121 S. Ct. at 972-973 (Breyer, J., dissenting) (citations omitted). For some of the constitutional theory literature exploring differences in legislative and judicial interpreta- 
Boerne and its progeny break with the doctrinal frameworks-and institutional understandings--through which the Court has defined Congress's power to enact civil rights legislation since the beginning of the second Reconstruction. ${ }^{12}$ The separation-of-powers problem that the Court now perceives in federal civil rights legislation appears because-in matters concerning the Fourteenth Amendment, at least-the Court now imagines itself as solely responsible for interpreting the Constitution's meaning.

Courts do play a central role in constitutional interpretation, and today most in our constitutional culture believe that courts have the final word in constitutional controversies properly presented to the Court. ${ }^{130}$ But the concept that courts play a central role in constitutional interpretation, or have the last word in constitutional controversies properly before them, is by no means the same as the claim the Court is now seemingly advancing: that the democratic branches of government have no independent authority to interpret the Constitution once the Court has declared its meaning. ${ }^{131}$

What resources does constitutional theory offer to evaluate the picture of our constitutional order depicted in Boerne and its progeny? Considerably fewer than it otherwise might, because so much of constitutional theory is court-centered in its account of constitutional interpretation. For the last several decades of the twentieth century, constitutional theory wrestled with the charge that judicial review was "counter-majoritarian" or otherwise antidemocratic. But it now needs to explore a different question: in our constitutional tradition what is the role for constitutional interpretation outside the courts? Juricentric accounts of our constitutional tradition, such as Strauss's account of common law constitutionalism, do not address such questions but may lend tacit support to the picture of our constitutional order that undergirds Boerne.

What we need instead are more empirical and theoretical resources for wrestling with the deep questions of interpretive authority that Boerne raises. For instance, under what circumstances do diver-

tion of the Constitution, see supra note 13.

${ }^{129}$ Post \& Siegel, supra note 13, at 486-502, 513-22.

${ }^{130}$ For a historical account of concepts of judicial supremacy and modern challenges to it, see Kramer, supra note 13.

191 Cf., Garrett, 121 S. Ct. at 968 ("[T]o uphold the Act's application to the States would allow Congress to rewrite the Fourteenth Amendment law laid down by this Court in Cleburne."). 
gent understandings of the Constitution vitalize our tradition, and when do they pose a threat to it? What kinds of conformity best serve and preserve the Court's authority to say what the law is?

Any account of the Court's role in constitutional interpretation must locate the Court among the many institutions and individuals that make claims about the Constitution's meaning. As this Article has argued, there is much work to be done in describing the role that nonjuridical actors play in shaping constitutional meaning, whether citizens speak in the streets, in Congress, in the executive branch, or through lawyers in the courts. By no means do all chapters of this story involve nonjuridical actors defying judicial authority-unless we propose to treat every claim about the Constitution's meaning that is advanced by a nonjuridical actor as a challenge to the Court's authority to say what the law is. That would certainly amount to a novel, and dramatic, departure from the understandings and practices composing our constitutional tradition. To the contrary, we need to understand judicial review as a practice that regularly occurs in the midst of constitutional mobilizations, and so frequently involves courts intervening in constitutional disputes that are unfolding among constitutional interpreters outside the courts. The complex questions of institutional role and institutional authority in matters of constitutional interpretation raised by the Court's recent Section Five cases fall outside the boundaries of this Article, ${ }^{132}$ but one important aspect of the question lies at its core: The Court regularly interprets the Constitution amidst competing claims about its meaning, and does not, and cannot, establish its authority by silencing alternative understandings.

Polyvocality in matters of constitutional interpretation regularly occurs in our constitutional culture. When citizens engage in constitutional interpretation, they enact and reinforce understandings of the Constitution's democratic authorship. The fact that elected officials and ordinary citizens are making multiple and conflicting claims about the Constitution's meaning need not be a threat to the Court's authority and, in our democratic constitutional culture, may well be a necessary condition of it. If citizens and elected officials concern themselves with constitutional questions, they are engaged in a common enterprise with the Court, even when they are in disagreement with the Court. Active engagement with constitutional questions may

\footnotetext{
${ }^{192}$ For a more extended analysis of the Section Five question, see generally Post \& Siegel, supra note 13.
} 
well produce fidelity to constitutional values in ways that passive obedience to the Court's authority cannot. Further, when the Constitution has multiple and socially dispersed interpreters, the Court is likely to interpret the Constitution in ways that are informed by evolving popular judgments about the Constitution and issue judgments that find support among a diverse array of social actors. The fact that the Court must often decide cases in ways that run against popular sentiment does not mean that it can dispense with the need for popular support. In matters that genuinely arouse popular passions, the Court requires popular engagement with constitutional questions to secure its authority.

A look at our constitutional history suggests that judicial supremacy is, in important respects, a collaborative practice, involving the Court in partnerships with the representative branches and the People themselves. All of these relationships are in fact part of the Little Rock story, properly understood. As I have elsewhere argued, without the executive branch, the Congress, and the civil rights movement itself, the Court could not have fashioned or enforced the Brown $v$. Board of Education ${ }^{133}$ opinion on which its modern reputation stands. ${ }^{134}$

What tacit picture of constitution making will fund decisions about the respective roles of Congress and the Courts in matters of constitutional interpretation? This is an "internal" question of constitutional theory that deserves a much thicker positive description of practice in our constitutional tradition than constitutional theorists have thus far provided. If we describe the understandings and practices that support communication about constitutional meaning in our constitutional order, examine the rich and varied histories of constitutional mobilizations, and trace the genealogy of venerated constitutional concepts, we will discover that the Constitution's popular authorship is not merely legal fiction. In our tradition, the People continue to play a role in authoring constitutional understandings in ways that involve acting inside and outside formal processes of law.

\footnotetext{
133347 U.S. 483 (1954).

${ }^{134}$ Post \& Siegel, supra note 13, at 516.
} 
* * * * * * *

HeinOnline -- 150 U. Pa. L. Rev. 352 2001-2002 